University of Warwick institutional repository: http://go.warwick.ac.uk/wrap This paper is made available online in accordance with publisher policies. Please scroll down to view the document itself. Please refer to the repository record for this item and our policy information available from the repository home page for further information.

To see the final version of this paper please visit the publisher's website. Access to the published version may require a subscription.

Author(s): Steve Hindle

Article Title: Imagining Insurrection in Seventeenth-Century England:

Representations of the Midland Rising of 1607

Year of publication: 2008

Link to published version: http://dx.doi.org/ 10.1093/hwj/dbn029

Publisher statement: This is a pre-copy-editing, author-produced PDF of an article accepted for publication in History Workshop Journal following peer review. The definitive publisher-authenticated version [Hindle, S. (2008). ilmagining Insurrection in Seventeenth-Century England: Representations of the Midland Rising of 1607 . History Workshop Journal, 66, 1, pp. 21-61.] is available online at: http://dx.doi.org/ $10.1093 / \mathrm{hwj} / \mathrm{dbn} 029$ 


\title{
Imagining Insurrection in Seventeenth-Century England: Representations of the Midland Rising of $1607^{*}$
}

\author{
STEVE HINDLE \\ University of Warwick
}

In early June 1607, Gilbert Talbot, earl of Shrewsbury, reported that a crowd of approximately one thousand men and women had begun 'busily digging' in enclosures at Newton, three miles north of Kettering in Northamptonshire. ${ }^{1}$ Although Shrewsbury personally regarded these 'diggers' as a 'tumultuous rable', he noted that they called themselves - in what may well be one of the earliest uses of that resonant term'levellers'. ${ }^{2}$ Their objectives, like those of many enclosure rioters, were to bury the hedges and destroy the fences of a local landlord, in this case those recently erected by Thomas Tresham. The Northamptonshire diggers' activities, however, escalated over the course of several days, eventually culminating in a bloody pitched battle with the local gentry. Contemporaries accordingly felt justified in referring to the participants not only as 'levellers' or 'diggers'; but even as 'rebels in the highest degree'. ${ }^{3}$

Trouble had been brewing in this part of Northamptonshire since the festivities associated with May Day. The county militia were nonetheless ill-prepared, some of the mustered men probably becoming disaffected out of sympathy for the protesters. The local gentry were therefore obliged to assemble a makeshift force from their own household servants and clients. This private army was led by two highly-experienced gentlemen, Sir Edward Montagu of Boughton, one of the deputy-lieutenants of the county, and Sir Anthony Mildmay of Apethorpe, a veteran of the campaign against the Northern Rising of $1569 .{ }^{4}$ It is uncertain how long the levellers had camped themselves at Newton before what proved to be the final confrontation, for some negotiation apparently took place between Montagu and the townsmen of Kettering in particular. ${ }^{5}$

By 8 June, however, Montagu's patience had been exhausted, and after summarily executing two of the diggers' leaders under martial law, he and Mildmay were ready to proceed. ${ }^{6}$ They began by reading the royal proclamation of 30 May, which 
charged the protesters with seditious libel for criticising the government's failure to prosecute enclosing landlords; and threatened to crush them with 'force of arms' if they did not disperse. Montagu and Mildmay apparently used 'all the best persuasions' to encourage the crowd to dissolve, and read the proclamation a second time. 'When nothing would prevail', however, the gentry force 'charged them thoroughly with both horse and foot'. At first, the crowd stood fast and 'fought desperately', but 'at the second charge they ran away', and in the rout 'some 40 or 50 of them' were slain and 'a very great number hurt'. Many more were apprehended, and several were subsequently executed, either after due process at a special judicial commission convened at Northampton on 21 June; or summarily under martial law according to the terms of a second royal proclamation of 28 June. The quartered carcasses of the guilty men were exhibited at Northampton, Oundle, Thrapston 'and other places', a pattern which implies that there had been some sympathy for the Rising in these towns. ${ }^{7}$ Although there were aftershocks, with rumours of conspiracy circulating long after the executions, Montagu was confident that the battle and subsequent hangings had pacified the country north of Kettering which now, he reported, 'stands quiet'. ${ }^{8}$

The carnage at Newton represented the culmination of six weeks of disorder across the three counties of Leicestershire, Northamptonshire and Warwickshire. Contemporaries differed in the terminology-'commotion', 'insurrection', 'pernicious treason'-with which they characterised these episodes. Although they have collectively become known among historians as 'the Midland Revolt', the term 'Midland Rising' seems more appropriate. ${ }^{9}$ The long-term context of this rebellion was the significant population growth and associated price-inflation of the sixteenth century, which resulted in increasing differentials of wealth between rich and poor. ${ }^{10}$ The growing burden of poverty created by these pressures was compounded in 1593 when the Tudor regime for the first time relaxed its restrictive laws against the enclosure of those common fields and wastes upon which the livelihood of the landless poor depended. The gentry of the heavy 
clay-lands of the midlands recognised this legal innovation as an opportunity to convert their estates from the growing of grain to the rearing of sheep for wool and the fattening of cattle for dairying, and continued to do so even after the laws were hurriedly reinstated in 1597. Many open-field communities therefore experienced rapid and sometimes complete enclosure in the decade or so before $1607 .{ }^{11}$ Among these villages were Cotesbach (Leicestershire); Ladbroke, Hillmorton and Chilvers Coton (Warwickshire); and Haselbech, Rushton and Pytchley (Northamptonshire). Each of these places saw significant crowds of 'levellers' and 'diggers', allegedly as numerous as five thousand, protesting against depopulation in May and early June $1607 .{ }^{12}$ It is, accordingly, fitting that the Rising culminated at Newton, the site of a particularly notorious episode of oppressive enclosure. ${ }^{13}$

The Midland Rising is all-but-forgotten, even among historians of early modern rebellions. This amnesia might partly be explained by archival attrition, especially the disappearance of depositional evidence taken during the interrogation of its ringleaders. It is also a function of historiographical uncertainty about the most appropriate genre of social protest with which to associate the Rising. In some respects, the episode might be dismissed as a sequence of glorified enclosure riots. ${ }^{14}$ In others, it more closely resembles the insurrections of the 'commotion time' of $1549 .{ }^{15}$ Because it took place under James I, however, the Rising does not figure in the roll-call of 'Tudor rebellions', constructed within the conventional periodisation of dynastic succession, where it might comfortably take its place. It is, indeed, arguable that this attack of historiographical amnesia is structural, a deliberate act of forgetting which relegates to oblivion an episode which contradicts the widely accepted meta-narrative in which the dying tradition of disorder was killed off by skilful political management. After all, the scale and duration of the Rising, and the volume of blood shed at Newton-field and on the gallows of Northampton, undermine the common historiographical assumption that the Tudors had successfully pacified the commons of England. ${ }^{16}$ 
The current orthodoxy is that by the end of the sixteenth century the rural elite, including both the gentry and the middling sort who had once provided the natural leadership of popular protest, had distanced themselves from the tradition of disorder. Their withdrawal, it is argued, explains 'the poor's increasing inability to translate discontent into rebellion', a tendency apparently confirmed by the abject failure of the abortive Oxfordshire conspiracy of $1596 .{ }^{17}$ There was, to be sure, considerable 'momentum for obedience' in late Elizabethan and early Stuart society. ${ }^{18}$ Nonetheless, only a decade or so after the public execution of the Enslow Hill conspirators, and even without the participation of those yeomen who had long been the usual suspects when the authorities were rounding up rebel ringleaders, the poor commoners of the Midlands seem to have mobilised discontent on an extraordinary scale in 1607. Crowds of 'diggers' led by a man who was contemptuously dismissed as an itinerant tinker forced the regime first into the catastrophe of slaughtering dozens of its own subjects; and subsequently (as we shall see) into the humiliation of reconsidering its attitude to the enforcement of the laws against depopulating enclosure. ${ }^{19}$ This is not to argue, however, that the poor enjoyed unconstrained agency in the negotiation of the terms, let alone the fact, of their subordination. ${ }^{20}$ Indeed, the articulation of plebeian grievances was the achievement of a popular politics fought out in the context of a profoundly unequal and often cruel class structure. $^{21}$ The participants in the Rising, whether they were 'levellers' or not, recognised oppression when they saw it; and it was precisely because they could not count upon local magistrates to enforce the enclosure statutes, that they decided to take those very laws into their own hands. ${ }^{22}$ Their protest ended in bloody sacrifice, but the crown was subsequently forced to redress their grievances in a series of prosecutions which suggested that, like grain hoarders, enclosing landlords were not only enemies of the people, they were also enemies of the state. ${ }^{23}$

This essay reconstructs the discourses of hunger, protest, paternalism and punishment associated with the Midland Rising. Although it presents some new evidence 
about the grievances of the crowds who gathered in Midland villages, it emphatically does not pretend to offer a full-scale narrative history of the episode, though one is certainly long overdue. Rather, it discusses in detail four commentaries contemporary, or near-contemporary, with the Rising in order to disclose the assumptions that were in play in the politics of popular protest; and to analyse the priorities of church and state when confronted both with a magisterial class reluctant to enforce laws which they regarded as inimical to their economic self-interest and with crowds of poor labouring men and women only too keen to administer justice on the King's behalf. In smashing fences and burying hedges, after all, the levellers gathered at Newton and elsewhere were mimicking, perhaps even mocking, the behaviour expected of magistrates when confronted with illegal enclosures. ${ }^{24}$ That mimicry implies an alliance between crown and crowd which recalls the volatile association between the regime of Protector Somerset and the 'commotioners' of 1549 who were convinced, and perhaps even encouraged to believe, that the law (and in principle the king) were in sympathy with their actions. ${ }^{25}$

Our four commentators might even stand, in the dialogic mode of academic analysis characteristic of the renaissance, as spokesmen for their respective estates. Indeed they might be regarded as participants in precisely the kind of conversation first rehearsed in 1549 by Sir Thomas Smith, whose celebrated Discourse of the Commonweal remained unpublished until 1581. Smith's Discourse took the form of a dialogue between a knight, a merchant, a craftsman, and an husbandman (as representatives of the different social groups who 'grieved' at their experience of economic and social change), and a doctor of divinity, effectively Smith's alter ego, who summarised their sectional interpretations of the situation. ${ }^{26}$ The four protagonists considered here are, respectively, a commoner (the tinker and rebel leader John Reynolds, popularly known as 'Captain Pouch'); the monarch himself (James I of England and VI of Scotland); a clergyman (Robert Wilkinson, chaplain to the Lord Lieutenant of Northamptonshire); and, finally, 
a very experienced lawyer and statesman (the Solicitor-General Sir Francis Bacon). Of course these four individuals did not actually enjoy a convivial evening's discussion over venison pasties washed down with claret, but we might read (as contemporaries surely would have read, had they seen or heard them) their analyses of social protest as a subconscious symposium among those whose economic and political interests were at stake during the early summer of 1607 . Such a reading is rendered more plausible by the fact that our commentators shared a common stock not only of familiarity with the events of the Rising, but also of idioms in which to discuss them. In their use of scriptural imagery from the Old Testament prophets, especially Isaiah; in their rehearsal of the rhetoric of the body politic; but most of all in their repeated allusions to empty bellies, the insights offered by Reynolds, by James I, by Wilkinson and by Bacon constitute a discourse of shared understandings of the possibilities and perils of popular protest. In relating these commentaries to one another, and in exploring the possibility that there was within twelve months a fifth attempt to dramatise the dynamic of the Rising, I suggest that this 'dialogue' discloses the complex ways in which insurrection was not only described, but might be represented and perhaps even imagined, in seventeenth-century England.

\section{I: The Commoners}

The motives of the Midland 'levellers' can only be conjectured, for those camped and subsequently slaughtered at Newton left behind no manifesto. The Rising nonetheless represented a continuation of petitioning by other means, for the people of Northamptonshire had recently complained both to the King and to the House of Commons about the evils of enclosure. In 1603, King James had passed through the county en route to London, and had encountered great crowds of people complaining of recent enclosures committed by 'wolfish Lords, that have eaten up poor husbandmen like sheep'. In 1604, Sir Edward Montagu himself had informed the Commons in his capacity as MP for Northamptonshire that the 'cry of the county' was vehemently against 
'depopulation and daily excessive conversion of tillage into pasture'. ${ }^{27}$ Both appeals apparently fell on deaf ears, for grievances of precisely this kind were subsequently reiterated with remarkable rhetorical prowess by the self-proclaimed 'poor delvers and day labourers' of Warwickshire during the early summer of 1607. Cast and circulated as a manuscript 'bill' or 'libel', their rallying cry to all the other 'diggers' in the county was subsequently described by James I as one of the 'wicked instruments' through which insurrection had been organised. ${ }^{28}$ Perhaps this broadside, like the contemporary libel 'made against the knightes and justices' of Northamptonshire (copies of which fetched a shilling a piece), was bought and sold in alehouses across the Midlands. ${ }^{29}$

The authorship of the digger broadside remains obscure. Leadership appears, however, to have been provided by John Reynolds, reputedly a pedlar or tinker by trade, who became known as 'Captain Pouch' because of the leather satchel which, he claimed, contained 'sufficient matter to defend them against all comers' (though on his apprehension, Reynolds' pouch was allegedly found to contain only a piece of mouldy cheese). ${ }^{30}$ Reynolds had nonetheless played a significant role in co-ordinating antienclosure protests across Northamptonshire and Warwickshire in May and early June, and claiming to have authority both from God and the King to destroy hedges and fences, recruited very large assemblies of protesters at significant sites of enclosure. One of his followers subsequently told the authorities that 'Captayne Powche had authoritie to cut downe all enclosures betweene ... Northampton and the cytie of Yorke'. ${ }^{31}$ If Reynolds really was the 'chiefest leader' of these protests, he brought to bear both a significant degree of local knowledge in choosing the most appropriate targets and a high level of political skill in disciplining his followers into orderly protest. ${ }^{32}$ Even hostile witnesses remarked that the gatherings of the Midland Rising were essentially orderly: Reynolds instructed his followers 'not to swear, nor to offer violence to any person, but to ply their business and make fair works'. ${ }^{33}$ Although he may well have helped compose the digger broadside, Reynolds himself was apparently not present at Newton, having 
being apprehended at Withybrook (Warwickshire) in early June, though he was apparently among those convicted and executed at Northampton. The lack of any extant examinations or depositions in Reynolds' case deprives him of the kind of voice which echoes through the 'archive of repression' relating to the Oxfordshire Rising some eleven years previously. ${ }^{34} \mathrm{He}$ was, however, probably no less well-informed as a student of the tradition of disorder than was his predecessor Bartholomew Steere, and his apparent silence is perhaps better described as the white noise generated by archival attrition.

It may well, therefore, have been Reynolds' voice with which the Warwickshire diggers bitterly criticised their landlords as 'encroaching tyrants which would grind our flesh on the whetstone of poverty' so that they 'may dwell by themselves in the midst of their herds of fat weathers' [i.e. rams]. In doing so, they made explicit allusion to two verses from the book of Isaiah: 'What mean ye that ye beat my people to pieces and grind the faces of the poor?' (iii: 15); and 'Woe unto them that join house to house, that lay field to field, till there be no place, that they may be placed alone in the midst of the earth!' (v: 8). Enclosure, the diggers insisted, was carried out not 'for the benefit of the Commonalty' but only for the 'private gain' of those who had 'depopulated and overthrown whole towns and made thereof sheep pastures, nothing profitable for our commonwealth'. The common fields and wastes, they argued, had yielded not only much-needed grain but also extensive 'comodity', including fish, fowl and fuel, on which their lives depended. So fragile had their economy become that only a single harvest failure would be needed to undo them altogether: 'there would be a worse, and more fearefull dearth happen then did in K[ing] Ed[ward] the seconds tyme, when people were forced to eat catts and dogs flesh, and women to eate theyr owne children'. ${ }^{35}$ They firmly believed that King James himself would be sympathetic to their fears, and would help them call to account those landlords who would 'deprive his most true harted comunalty' of their livelihoods. Should their confidence in royal redress prove misguided, however, they warned that they too cared little for 'life and lyvinge'. Rather than be starved to 
death for want of the very food which those 'devouring encroachers' were now feeding to their 'fat hogs and sheep', the diggers professed a willingness to 'manfully dye' in arms against their landlords. For many protestors, especially those assembled at Newton, those words (just as they had when rehearsed by the hungry poor of Oxfordshire in the dearth of the late 1590s) proved to be prophetic. ${ }^{36}$

The diggers' broadside, therefore, offers a coruscating critique, underpinned by a moral outrage infused with scripture, of the tyrannical evils of enclosure. But it also discloses the popular perception that, by converting arable to pasture, enclosing landlords were responsible for driving up the price of grain. Depopulation and dearth were, it seems, intimately linked in plebeian consciousness, an association which may have had particularly deep roots in the heavy clay soils of the Midlands which had long been regarded as most suitable for cereal production, but where common fields were increasingly being converted exclusively to pasture. As the local proverbial wisdom had it: 'the more shepe, the dearer is the corne'. ${ }^{37}$ The grievances associated with the digger broadside evidently reached the ears of the authorities. The earl of Shrewsbury reported in early June 1607 that the 'rable' sought 'reformation of those late inclosures which made them of the poorest sorte reddy to pine for wante', and hinted at a direct encounter with the Warwickshire justices during which the diggers' representatives undertook to disperse if King James promised within six days to reform the abuses associated with depopulation; and even persuaded Sir Thomas Leigh of Stoneleigh to convey their grievances to the privy council. ${ }^{38}$

Indeed the sophistication of the political economy which underpinned the Diogger broadside, of which Reynolds may or may not have been the author, is disclosed in a more explicit, but apparently retrospective, statement of the complaints which underpinned the Rising, surviving in the state papers. This undated manuscript rehearses thirteen 'grevaunces alleaged severallye by those that have pulled downe the hedges, pales of parkes \& chases $\&$ from those likewise that have encoraged them to doe the 
same'. ${ }^{39}$ These perceived consequences of enclosure may conveniently be divided into five categories: the extinction of common rights; the raising of rents; the decay of hospitality; depopulation and the concomitant increase in the burden of poverty; and the enhancement of the price of corn. The allegations were, in each respect, highly specific. The enclosure of commons (articles $4 \& 9$ ) had deprived commoners of the 'profitte' and 'comodite' (the latter a term also applied to the 'uses of waste' by the Warwickshire diggers) which they had traditionally derived from customs of pasture and fuel-gathering, and had driven them to squat at the margins of wastes where they took common 'without right' and therefore prejudiced the interests of 'rightful commoners' ${ }^{40}$ Once they had enclosed, landlords also racked their rents (articles $5 \& 6$ ) to such an extent that the 'people cannot well live' and even those who could make the payments were forced to raise the price of their dairy produce, especially butter and cheese, in order to make even a minimal profit. Hospitality (articles $7 \& 10$ ), which had long provided the 'poorer sort' with an invaluable source of charity and employment, could no longer be practised where landlords had either leased out their demesne or absented themselves, 'flocking to London and other places'. The resulting depopulation drove the poor into the market towns (article 1), where their immiserisation not only bred 'factious accons' but collapsed the demand for consumer goods on which the livelihoods of artisans and craftsmen depended. Their only alternative was to squat in unlawful cottages in the common woodlands (articles $9 \& 12$ ), where their numerous children either broke hedges for fuel or became a burden on the poor rates.

It is particularly striking, however, that three of the articles should associate enclosure with the dearth of corn. Conversion to pasture (article 2) had driven up the price of grain 'to such a rate that labourers and artificers in townes \& cities are not able to get ther lyveinges'. The racking of rents on arable lands (article 8) led husbandmen to export corn in search of securing a better price, thereby further destabilizing a grain market already vulnerable to the vicissitudes of the harvest. All this gave racketeers 
abundant opportunity to abuse the market (article 11), either by selling short weight, sometimes by as much as a gallon in a strike (i.e. by one-eighth), or by buying "by the greate measure' and selling 'by the lesse'. The 'grevances' of summer 1607 therefore echo the digger broadside in emphasizing the intimate but complex relationship between the enclosing of common land and the shortage of corn. Enclosure not only deprived the poorer sort of their livelihood, it also drove them out of the grain market. The Midland Rising, it seems, was provoked as much by dearth as by enclosure.

Indeed, poor consumers' fears about food supply and marketing abuses resurfaced in Warwickshire not long after the Rising was suppressed. They argued in June 1608 that the dearth of corn was 'caused partly by some that are well stoared' with grain 'refraining' to bring it to market because 'of a covetous conceit that corne will be dearer', and blamed continuing high prices on the failure of the magistracy to prevent 'conversion of errable land in pasture by enclosing' ${ }^{41}$ Concerns about dearth were also evident in the popular literature of the time. In November 1608, the Stationers Company registered the publication of two ballads offering diametrically-opposed assessments of the cause of high prices: the first, A Just Complainte Made by the Poore People of England Against the Covetousness of Greedy Fermours Which Cause a Dearth of Plentifull Thinges, argued that scarcity was artificial, the consequence of human greed; the second Exhorting all Synners to Require Gods Commiseration and Mercy for the Great Famine and Plague Which at This Instant We Justly Suffer, argued that it was providential, a judgement sent by God to provoke repentance and humiliation. ${ }^{42}$ Whatever the perceived causes of dearth, therefore, the Rising was subsequently associated with high corn prices. It was remembered by Arthur Standish in 1611 as a 'grievance taken only for the dearth of corne' in Warwickshire, Northamptonshire 'and other places'; and alluded to by John Moore in 1612 as 'a fearefull clamor' among 'painful plowmen, tradesmen and poor labourers, not able by their paines and gaines to furnish their families with sufficient foode'. ${ }^{43}$ 
This fusion of agrarian and marketing grievances arguably explains the peculiar confederation of participants in the Rising, which included not only the dispossessed tenants of depopulated Midland villages but also urban-dwellers struggling to make ends meet in the towns, especially Leicester and Kettering. ${ }^{44}$ This coalition represented a very significant threat to the early Stuart state, but its 'loops of association' seem to have been only loosely drawn together. ${ }^{45}$ The Venetian ambassador noted in late June (after Reynolds had been apprehended) that 'the rising of the peasants' had 'gone on growing from day to day to such an extent that they only required a leader to make it a formidable and open rebellion'. ${ }^{46}$ The crowd assembled at Newton was apparently, therefore, leaderless and faceless, cloaked in anonymity until several of them, as we shall see, sued Sir Edward Montagu for pardon later in the summer. As both the digger broadside and the subsequent iteration of grievances suggest, however, the crowds that constituted the Rising might have lacked names and status but they were short neither of moral authority nor of political voice. They explicitly condemned enclosure in the idiom of tyranny, as a crime committed by a propertied class who had little respect for the king's law, still less for their conventional social obligations.

\section{II: The Monarch}

The Crown's response to the Rising was entirely characteristic of its attitude to popular protest in Tudor and Stuart England. It is best expressed in a series of three royal proclamations issued in the late spring and early summer of 1607 . The first, of 30 May, a week before the slaughter at Newton, was intended to suppress those 'persons riotously assembled for the laying open of Inclosures'. The second, of 28 June, a week after the Northampton trial, supplemented James' restated intention to punish riotous assembly with a desire for reformation of depopulations. The third, of 24 July, signified 'his Majesties gracious pardon for the offendours about inclosures'. ${ }^{47}$ The extent to which these proclamations represented James' own views, and even more problematically his 
own rhetoric, must remain open to question. There is clear evidence that James was personally interested in the policy rehearsed in these proclamations: it was almost certainly after a meeting with the King in May 1607, for example, that the privy council instructed all MPs to return to their counties during the adjournment of parliament; and it was at James' insistence in February 1608 that the landlords named in the returns of the depopulation commission were prosecuted in the Star Chamber. ${ }^{48}$ But James' bombastic claim in the Commons in 1621 that he had dictated 'every word' of most of his proclamations is just that: bombast. ${ }^{49}$ Many proclamations were issued while he was away hunting at Royston or Newmarket, and at most he could only have made some corrections to a draft pre-prepared by Sir Robert Cecil. The destruction of the privy council register for this period, where evidence of the King's opinions may well have been recorded in the minutes of meetings, means that the extent of James' role in drafting the actual texts of the proclamations will probably never be known.

The proclamations nonetheless clearly reflect the priorities of his government. The first priority, as the Rising spread across the midland counties in late May, was to persuade the crowds to disperse, promising to deal with their complaints by the ordinary course of justice through the county commissions of the peace. ${ }^{50}$ But it rapidly became clear that such 'lenitie' had bred encouragement rather than obedience, and since the rebels were now 'presuming to gather themselves in greater multitudes', 'sharper remedies' were necessary. James castigated those who had trusted rather to their own 'pride and rashness' than to the 'care and providence' of their sovereign. ${ }^{51}$ The second priority, therefore, was repression: 'we will prefer', James insisted, 'the safety, quiet and protection of our Subjects in general, and of the body of our State, before the compassion of any such Offenders, be they more or less, and howsoever misled: and must forget our naturall clemency by pursuing them with all severity for their so hainous Treasons, as well by our arms as laws'. James characteristically deployed an organic metaphor to explain his policy: 'We are bound (as the head of the politike body of our Realme) to 
follow the course which the best Phisitians use in dangerous diseases, which is, by a sharp remedy applied to a small and infected part, to save the whole from dissolution and destruction'. ${ }^{52}$ The trial of the rebels at Northampton accordingly saw three categories of defendants arraigned before Sir Edward Coke, Chief Justice of the Common Pleas: a first group, including Reynolds himself, was indicted for high treason in levying war against the crown; a second for felony in disobeying the royal proclamation ordering them to disperse; and a third for the misdemeanour of 'unlawful assembly and throwing down hedges and ditches'. ${ }^{53}$ By Easter 1608, nine Northamptonshire men had been convicted in the Star Chamber, and fined in sums ranging from $£ 30$ to $£ 6$, for 'riotous breaking into an enclosure' during the Rising. ${ }^{54}$

The crown's third priority, however, was the redress of the very grievances which had provoked the Rising. Although the privy council had debated on 5 July whether or not to wait before initiating proceedings against depopulating landlords, noting in passing that their predecessors had waited fully two years before prosecuting the enclosers who had precipitated the 'commotion tyme' of 1549 , royal commissioners had by August 1607 been appointed to investigate the scale of illegal enclosure and depopulation across the midlands. ${ }^{55}$ James justified this decision very carefully: the policy was not born, he insisted, either of 'any apprehension or regard of these tumults and disorders'; nor was it intended 'to satisfie disobedient people be they rich or poore'. It was, rather, motivated by 'love of Justice'; by 'Christian compassion' for those subjects who 'being likewise touched with this grief, avoyded the like offences'; and by 'Princely care and providence to preserve our people from decay or diminution' ${ }^{56}$ Although the returns of the commissions of enquiry are incomplete, they demonstrate just how severely Northamptonshire had been affected by the behaviour of self-interested landlords: over 27,000 acres (almost a third of the property identified by a commission which had extended through seven counties) had been enclosed, resulting in the destruction of over 350 farms and the eviction of almost 1500 people across eighteen 
villages. ${ }^{57}$ The findings of the commissions were used, in turn, as the basis for prosecutions in the Star Chamber of those landlords who had enclosed their lands illegally. Several leading Northamptonshire gentlemen were convicted. ${ }^{58}$ Among them was Thomas Tresham of Newton, found guilty of the enclosure of four hundred acres and the destruction of nine farms in Newton. ${ }^{59}$

It is also striking that, as early as 24 July 1607 , James was offering a royal pardon to those offenders who remained at large. ${ }^{60} \mathrm{He}$ emphasised that 'of all other seditions and rebellions, none doth bring such infinite waste and desolation upon a Kingdom or State, as these popular insurrections' ${ }^{61}$ Although risings such as that which had convulsed the midlands 'seldome shake or indanger a Crowne', this one had brought 'a heape of calamities upon multitudes of innocent Subjects, and chiefly upon the authors and actors themselves'. Rebellion was, therefore, a self-cancelling act. ${ }^{62}$ And it was equally important to remind the rebels that they had not been provoked by genuine poverty: there had, James insisted, been no 'necessitie of famine or dearth of corne', nor indeed any other 'extraordinary accident', that might 'stirre or provoke' the labouring poor to rise. This reading of the economic situation may well have been plausible at the time, especially when viewed from Whitehall. The local experience of shortage in the Midlands was altogether less happy, with burials soaring across the Arden in the harvest year 1606-7. ${ }^{63}$ Within twelve months, moreover, the anxieties of the Warwickshire diggers were vindicated. By 1 June 1608, with corn prices having risen by 30 percent over the preceding twelve months, the Crown was forced to issue the 'dearth orders' under the terms of which the royal prerogative was used to regulate the grain markets. ${ }^{64}$

James scepticism about the nature and scale of dearth notwithstanding, he nonetheless thought it imperative to temper justice with mercy, and all the more so since the Rising had involved 'a number of poor and simple people', to whom 'natural clemencie' ought to be extended. ${ }^{65}$ It was under the terms of this third proclamation that Sir Edward Montagu at the end of September recorded the names of 143 persons who 
had pleaded for indemnity. Those who appeared before him at Boughton House probably included several of those who had been present at Newton on 8 June as well as many who had not. ${ }^{66}$ Our knowledge of those who were gathered at the final confrontation is, therefore, sketchy at best. It is nonetheless clear that six weeks after the pitched battle, and four weeks after the Northampton trials, there were still very significant numbers of rebels at large.$^{67}$ Conspiracy on this scale convinced James that he was confronted with a second 'commotion tyme', and as had been the case in 1549, crown policy insisted that rebels were first to be punished with retribution only subsequently to have their grievances redressed with 'princely care'. Indeed, this policy was theologically justified with the help of a gifted polemicist who explicitly condemned the Rising as a commotion, but was not entirely unsympathetic to the complaints of the 'rebels'.

\section{III: The Clergyman}

Our clergyman, Robert Wilkinson, is a far more obscure and in some ways enigmatic figure. He graduated MA at Pembroke College, Cambridge in 1588, and enjoyed his first preaching position in Horton Kirby (Kent), where he wrote his first work, $A$ Jewell for the Eare. In 1592, he was appointed by Thomas Cecil, the future earl of Exeter, as rector of the small Northamptonshire parish of Barnack, some eighteen miles north of Newton, where he remained until 1614. Although he had one foot firmly planted in the clay of the south Midlands, Wilkinson was no stranger to the royal court or the metropolis, and therefore conforms to the model of protestant clergyman as 'broker' between two social worlds. ${ }^{68}$ He became chaplain to Cecil sometime before 1607 and to King James himself in 1610. Although he was a 'conformist Calvinist', he was perfectly capable of preaching 'in the prophetic voice of Tudor reformers' ${ }^{69}$ By 1607 Wilkinson was already widely-known for his 'winning touch with homiletic', and especially for his ability to draw out complex metaphors in stylish and sustained fashion, 
and had accordingly been entrusted with preaching the politically-sensitive sermon at the court wedding of Lord and Lady Hay on Twelfth Night 1607, the published version of which (The Merchant Royall) followed his Jewel for the Eare into the best-seller lists. ${ }^{70}$

Wilkinson was evidently regarded as a safe pair of hands both by the King and by Cecil, who in his capacity as Lord Lieutenant appointed him to preach what was effectively an assize sermon at the sessions convened at Northampton on 21 June 1607 to try the Midland rebels. ${ }^{71}$ As might be expected of a court preacher speaking in the presence of the Lord Chief Justice, the Attorney-General and a jury empanelled from the great and the good of Northamptonshire society, Wilkinson emphasised his disgust at the very idea of insurrection. He was outraged that 'mechanicall men are come to beard magistrates'; horrified that 'the vile' dared to 'presume against the honourable'; and appalled that the ruler of three kingdoms was obliged to 'capitulate with a tinker'. ${ }^{72}$ The Rising was, he thought, symptomatic of 'tempestuous and troublesome times' during which 'want, not well digested, hath riotted to the hazard of all'. ${ }^{73}$ The choice of an alimentary metaphor is particularly striking: in a sermon on the evils of enclosure and its consequences, Wilkinson took bread as his central image and hunger as his guiding metaphor.

Wilkinson was, in fact, surprisingly equivocal in his analysis of the causes of the Rising, condemning not only 'the rebellion of the many' but also 'the oppression of the mighty': the 'excessive covetousnesse of some', he insisted, had 'caused extreme want to other[s]'. ${ }^{74}$ Taking his cue from Matthew iv: 4 ('man shall not live by bread onely but by every word that procedeth out of the mouth of God'), he reminded 'the many' that 'man liveth not by bread only' and urged them to 'waite with patience for those [things] which yet wee have not'. ${ }^{75}$ Wilkinson accordingly condemned the 'poverty without patience' which had tempted the 'mad and rebellious multitude' to use unlawful means to seek redress. ${ }^{76}$ The dispossessed were guilty, he argued, because they had not borne their suffering patiently. Conspiracy, riot and 'damnable rebellions' arose, he insisted, 'not 
from want of bread but through want of faith'. Plenty would have been provided if the poor had retained faith in the Lord: 'if yee will have bread', he advised the poor, 'conspire not in mutinies but conspire in mutual prayers; roote not up harmlesse hedges, nor rend up the bowells of the earth but looke up to heaven from whence yee shall have bread'. ${ }^{77}$ And in a skilful rhetorical step, he momentarily identified himself with the persecuted: 'If patiently we had borne the oppression which is put upon us', he pleaded, 'we by oppression had come to martyrdome'. But 'because of a little want', he argued, 'men have buried their patience' just as they had 'buried hedges'. ${ }^{78}$

On the other hand, however, Wilkinson admonished 'the mighty' that 'man liveth by bread', thereby exhorting the propertied to exercise their traditional obligations of charity and paternalism. ${ }^{79}$ In doing so, he actively promoted 'the cause and complaints of the expelled, half-pined and distressed poore' who had been driven to rebellion by the covetousness of the rich. ${ }^{80}$ Alluding to Isaiah (iii: 15), a passage that had also been deployed by the Warwickshire diggers, he insisted on the 'lesson for all states generally not to grind the faces of the poore ${ }^{81}$ Indeed, his condemnation of the mighty developed into a full-blown critique of economic oppression reminiscent of the famous passage in More's Utopia, subsequently elaborated in Thomas Becon's Jewel of Joy, in which 'greedy and wild' sheep 'devour human beings' and 'devastate and depopulate fields, houses and towns'. Wilkinson thought that a stranger travelling through Northamptonshire and finding 'so many thousands of sheepe [and] in so many miles not a thing like a man' might reasonably ask himself 'What? Hath there bin some sorceresse, some Circe, heere that hath transformed men into beasts or is it so that men and beasts have waged warre together but how was this battell fought that sheepe got the field? Or what men were these that ran away from sheepe? Yea rather what sheepe were these that throw downe houses, townes and churches?' 82 And in cautioning landlords against 'joyning house to house and land to land to be alone upon the earth', Wilkinson also quoted the second passage from Isaiah (v: 8) that had been rehearsed by the diggers. ${ }^{83}$ The logical 
conclusion of the process of depopulation, he believed, was that the enclosing landlord would hang even his last remaining shepherd and keep his sheep himself. ${ }^{84}$

Confronted with such greed and oppression, Wilkinson believed that it was inevitable that the dispossessed should turn to crimes of necessity. Very significantly, he employed not merely an organic, but a specifically visceral, metaphor for the complaints of the poor: 'the belly sayth that bread must be had, and the soule subscribeth that bread must be had too, and though reason may persuade and authoritie command, and preachers may exhort with obedience and patience to sustain the want of bread', yet 'in case of extreame hunger men will not be perswaded' and 'they will have bread' ${ }^{85}$ This amounted to a sympathetic assessment of the social theory of necessity, the view that the attacks on private property were justified in cases of starvation. ${ }^{86}$ Wilkinson accordingly cited the commonplace wisdom of the day that 'Venter non habet aures' ('the belly has no ears'), a phrase that had been rehearsed and recognised as proverbial by Thomas Becon, Wilkinson's mid-Tudor predecessor as moralist and social critic, in $1550 .^{87}$

Enclosure had, therefore, provoked rebellion among the dispossessed and the hungry. By removing the staff of life, landlords had 'turned men into beasts and made them wilde and rebellious, which before were tame and obedient', and had ultimately transformed 'living bodies into dead carkases'. Although the rebels had 'justly perisht in their rebellion', Wilkinson reminded his audience of Christ's condemnation of those 'by whom the offence commeth! ${ }^{88}$ Several of those gentlemen assembled to witness, and in some cases to participate in, the proceedings, must have squirmed in their pews as Wilkinson publicly castigated the conduct of those enclosing landlords who had devastated the Northamptonshire countryside and left its people in hunger and despair. ${ }^{89}$ In noting that 'it was no part of the common powre [i.e. power]' to meddle with enclosures, Wilkinson was at the very least implicitly conceding that there was such a thing as popular political agency, even though he was explicitly concerned with defining the limits of its moral legitimacy. ${ }^{90}$ 
Lest his position seem too sympathetic to the rebels, however, Wilkinson closed by weighing the sins of the protagonists against one another. He thought that the offences committed by the rebels were significantly more heinous. The 'pasture men' [enclosers] indeed 'do horrible mischief', he argued, 'but they do it by degrees: first one breaks the law, and then another is [em]bold[ened] to break it by example'. 'Evils of such passage', he believed, 'are more easily prevented; but that which grows by mutinies being sodaine and violent is lesse resistible'. And the scale of the havoc perpetrated by each side was incommensurable: 'pasture men indeed destroy a fewe townes, but mutineers by civill comotion depopulate whole kingdoms'. ${ }^{91} \mathrm{He}$ was also, moreover, sensitive to the possibility that genuine economic grievances shared by a few might rapidly lead to a reckless campaign to overthrow the state: 'The comon proceding of popular mutinies', he believed, was 'first to murmur upon some just cause' but subsequently 'to murmur not for want but for wantones'. ${ }^{92}$ Wilkinson genuinely believed there were levelling tendencies at work in the Rising: their 'murmuring' expressed ambitions to 'change the state' and 'put off Moses and have another to guide them' (Numbers xiv: 1-5), and their 'conspiracy' insisted that 'all the congregation was holy' and that 'they would have no head at all'. ${ }^{93}$ Like the earl of Shrewsbury, Wilkinson feared that levellers' pretensions were not merely agricultural but social and political, and would culminate in the creation of an acephalous regime. diggers, he implied, might not merely be levellers of social distinction, they may even become tribunes of the people.

In a coruscating critique of rebellion as process, he imagined the inevitable radicalisation of what he regarded as a 'creeping conspiracie'. ${ }^{94}$ At first the rebels appeared only in broad daylight, like simple men with shovels and spades intending to return the earth to her native tillage, professing nothing but a desire to throw down enclosures, and departing when requested because they retained respect for authority. Before long, however, they were abroad in the night-time, with weapons in one hand and working tools in another, professing themselves as ready to fight as to work, and refusing 
to disperse because they despised authority. In the end, Wilkinson suggested, the rebels were reckoning for other matters than enclosure: 'accounting' with the clergy; giving counsel 'to kill up gentlemen'; and vowing to 'level all states as they levelled bankes and ditches'. ${ }^{95}$ Some of them, he believed, preached the escapist 'politics of cockayne', boasting that 'they hoped to worke no more'. ${ }^{96}$ To be sure, some of the rebels 'meant no more but the reformation of one abuse'. But even limited protest on this model could not be defended, still less excused, for it could never be 'in the power of rebelles to limit and stint rebellion as they list'. It was an 'easie matter to begin a commotion', yet 'no easie matter to stay it'. ${ }^{97}$ He concluded by justifying the judicial carnage meted out during and after the rebellion: 'better one or a few to be punisht than a whole kingdom hazarded'. ${ }^{98}$ And he added a word of caution for those conspirators still at large: the men slaughtered at Newton and butchered at Northampton had never believed themselves guilty of the sin of rebellion until they lay 'bleeding and groning their last upon the ground' or 'confessed themselves penitent' upon the gallows. ${ }^{99}$ Like James I, Wilkinson believed that all conspiracies were bound to end in repentance and death, and that treason inevitably consumed her own offspring. Why, therefore, embark upon it at all? Better, Wilkinson insisted, to be thankful for those good things we have: in the absence of bread, the poor should feast on faith.

Although Wilkinson's central and repeated allusion to bread was figurative (an encouragement to consume spiritual rather than literal food), it had the rhetorical effect of emphasising the physical hunger of the rioters, who were implicitly portrayed as victims both of enclosure and of dearth. It is, moreover, striking that Wilkinson's was capable of offering a highly materialist reading of Matthew iv: 4, especially in warning that 'the belly has no ears' and that 'in case of extreme hunger men will not be perswaded but they will have bread'. ${ }^{100}$ In emphasising the dangerous effect on the body politic of the hunger-pangs of the belly, furthermore, Wilkinson moves towards the position famously adopted by the fourth of our commentators, Sir Francis Bacon. Like Bacon, 
Wilkinson was clearly writing under the shade of government patronage. Within three weeks of its delivery, and almost certainly at Thomas Cecil's insistence, the Sermon Preached at Northampton found its way into print, where it served as valuable propaganda against those enclosing landlords who were shortly to find themselves arraigned in the Star Chamber. ${ }^{101}$

\section{IV: The Lawyer}

Sir Francis Bacon's early career is too familiar to require detailed rehearsal here. For our purposes it is significant that his rise to preferment coincided with the Stuart succession, he being appointed in 1604 as King's Counsel and on 25 June 1607, at the very height of the Midland Rising, as Solicitor-General, the second most significant lawofficer of the crown behind Attorney-General Sir Henry Hobart. By 1608, he was clerk to the Star Chamber, a court that was to assume particular significance in the aftermath of the Rising. ${ }^{102}$ But it is Bacon's role as an essayist which is most significant for our understanding of the perceived relationship between crown policy and popular protest. Sometime between 1607 and 1612, although it remained unpublished until 1618, Bacon drafted a short essay entitled 'Of Seditions and Troubles' in which he described his preferred strategy for the prevention of insurrection. ${ }^{103}$

As a Crown lawyer, Bacon might have been expected to offer a robust rehearsal of the imperative to obedience implied by the rule of law and the logic of exemplary punishment. As we shall see, however, his reading of the causes of popular protest was remarkably sympathetic to the rebels. Indeed, it epitomises his stance as the 'would-be philosopher statesman of the Jacobean commonweal'. ${ }^{104}$ This ambition had, in fact, originated at least as early as his parliamentary speeches in defence of tillage in $1597 .{ }^{105}$ Bacon's imaginative analysis of the political culture of insurrection was divided, with the precision that increasingly came to characterise his essays, into three parts, discussing in turn the Materials, the Motives and the Remedies of sedition (11.73-75). ${ }^{106} \mathrm{He}$ began with the 
materials, a choice justified on the grounds that 'the surest way to prevent Seditions' was 'to take away the Matter of them. For if there be Fuell prepared, it is hard to tell, whence the Spark shall come, that shall set it on Fire' (11.77-80). Given that the social fabric was so highly flammable, it was crucial to prevent its ignition. ${ }^{107}$ The wisest statesman, Bacon implied, would take pre-emptive action to dissolve the popular grievances which were crystallising around the two poles of 'Poverty' and 'Discontentment' (11.81-82). But where those two issues were conjoined, a peculiarly unstable compound would be created. If 'Poverty, and Broken Estate, in the better Sort, be joyned with a Want and Necessity, in the meane People', he warned, 'the danger is imminent, and great' (11.88-91). Pessimism and frustration among the landed elite would, therefore, catalyse crimes of desperation among the landless poor, who would be propelled by sheer hunger into open protest. In a telling echo of Wilkinson's comment that 'the belly has no eares', Bacon was convinced that 'the Rebellions of the Belly are the worst' (11.91-92). ${ }^{108}$ Indeed, Bacon carried forward this visceral metaphor from his discussion of the first material cause of seditions, poverty, into the second, discontentment. 'Discontentments', he argued, 'are in the Politique Body, like to Humours in the Naturall [body], which are apt to gather a preternaturall Heat, and to Enflame' (11.92-94). In sum, the Crown must be vigilant, identifying grievances when they arose, redressing them where appropriate and ensuring that a community of common interest was not created among those of varying social status who might for disparate reasons be unsympathetic to the regime.

His discussion of the 'Causes and Motives' of seditions was rather briefer but even more sophisticated, and reads like the chapter headings of a modern text book of political science. Grievances might arise, he wrote, over 'Innovation in Religion; Taxes; Alteration of Lawes and Customes; Breaking of priviledges; General Oppression; Advancement of unworthy persons; Strangers; Dearths; Disbanded Soldiers; [and] Factions grown desperate' (11.111-15). All these, he feared, 'in offending People, joineth and knitteth them in a Common Cause' (11.115-16). This was an astute analysis born of familiarity not only with the history of 
classical Rome, from which he cited numerous examples, but also that of Tudor England where all these issues - from harvest failures to demobilisation, from uncontrolled faction to evil counsel, from the reformation of religion to new principles of revenue-raisinghad provoked popular protest, frequently involving a dangerous alliance between the landed elite who exercised their political prerogatives to decide who should run the country and the middling sort who claimed the moral right to decide how the country should be run. ${ }^{109}$

Since the list of causes and motives was so extensive, the suggested remedies and preventions were correspondingly wide-ranging. In the first place, the crown's priority must be 'to remove by all means possible, that materiall Cause of Sedition . . . which is, Want and Poverty in the Estate' (11.121-23). The state had an obligation to secure the prosperity of all its citizens in a commonwealth which would ring with the rhetoric of social justice proclaimed in progressive policies of social amelioration and economic regulation. Thus Bacon transformed a 'conventional discussion of the art of managing men' into 'a set of rules for the welfare of a state'. ${ }^{110}$ Bacon specifically advocated the 'Opening, and well Balancing of Trade; the Cherishing of Manufactures; the Banishing of Idlenesse; the Repressing of waste and Excesse by Sumptuary Lawes; the Improvement and Husbanding of the Soyle; the Regulating of Prices of things vendible; [and] the Moderating of Taxes and Tributes' (11.124-28). To be sure, some items on this agenda harked back to late medieval strategies for the preservation of the social order: sumptuary control, for instance, both in sense of regulating dress codes and of exhorting the populace to eat frugally had been abandoned in the late sixteenth century after decades, perhaps even centuries, of legislative action. ${ }^{111}$ In other respects, Bacon's proposals idealised a social policy which was to some extent already enshrined in existing statutes and proclamations, especially in the tillage statutes of 1563 , the Elizabethan poor laws of 1598 and 1601 and in the book of 'dearth orders' first issued in 
1587. ${ }^{112}$ This, then, was a manifesto of agrarian and industrial policies of which even the mid-Tudor commonwealthsmen could only dream. ${ }^{113}$

In 'Of Seditions and Troubles', Bacon even offered an apology for the redistribution of wealth: 'above all things', Bacon wrote, 'good Policie is to be used, that the Treasure and Moneyes, in a State, be not gathered into few Hands. And Money is like Muck, not good except it be spread' (11.154-58). In emphasising that 'a State may have a great Stock, and yet starve', moreover, Bacon explicitly alluded to the hoarding of grain. The primary focus of this policy, he insisted, should be on 'suppressing, or at the least, keeping a strait Hand, upon the Devouring Trades of Usurie, Ingrossing, great Pasturages, and the like' (11.158-60). Enclosure had, in fact, long loomed large on Bacon's agenda of those economic practices which undermined the health of the body politic by concentrating wealth in the hands of the few. ${ }^{114}$ It is nonetheless clear that although he was extremely sensitive to the immediate causes of discontent, Bacon was concerned to deny legitimacy to rebels. ${ }^{115}$ Had Bacon had his way, however, enclosure would have remained illegal and the grievances which provoked the Midland Rising would never have had the opportunity to grow. Returning to his favourite metaphor of the stomach, he was convinced that 'maligne Ulcers, and pernicious Imposthumations' would develop only where the statesman turned 'the Humors backe' and allowed the 'Wound' to 'bleed inwards' (11.178-80). Only in the very last analysis does Bacon's account encourage the prince to sport the iron fist rather than the velvet glove. The monarch should always ensure that he had 'some Great Person, one, or rather more, of Military Valour, neere unto them, for the Repressing of Seditions' (11.229-31). But the crown should ensure that 'such Military Persons, be Assured, and well reputed of, rather than Factious, and Popular; Holding also good Correspondence, with the other Great Men in the State; Or else the Remedie, is worse than the Disease' (11.237-40).

Bacon's analysis is not only remarkably forceful in its apology for paternalism, it also echoes many of the dynamics of the Midland Rising: the pre-eminence of enclosure 
in the complaints of the rural poor; the importance of perceived as well as actual wrongs in the imagination of the hungry; the sudden crystallisation of a grievance held long in suspension; the importance of 'libels and licentious discourses against the state' as a sign of trouble; the need for military repression if sedition led to open insurrection. Only in his confidence that the labouring poor were people 'of slow motion' (11.166-67) who could not successfully mobilise themselves, and would perforce turn to the landed elite for leadership, does Bacon's critique seem misguided, perhaps even naïve. After all, the Midland Rising was emphatically not an alliance of the nobility and the commons: it was led by a man who, although he claimed to have the King's commission to throw down enclosures, was nonetheless an itinerant tinker. The rural poor of the south Midlands were evidently not as apathetic as Bacon fondly, perhaps even patronisingly, imagined. Above all, however, Bacon emphasised the importance of hunger in provoking insurrection, and the image of the stomach was recurrent in his writing: in his last desperate attempt to defend what had arguably, by 1620, become 'an unsustainable commonweal-position' Bacon returned once more to the metaphor of the belly. ${ }^{116}$ In proposing some 'commonwealth bills that may add respect to the King's government and acknowledgment of his care' he insisted he was 'providing good matter to set the parliament on work' in order that 'an empty stomach do not feed upon humour'. ${ }^{117}$ But the deliberate shift in the signifier is surely significant: in 1607, the 'belly' had been associated with the hungry poor; by 1620 it had become a metaphor for the legislature. And this ambiguity in identifying the referent of the belly was, as we shall see, particularly significant in the years immediately following the Midland Rising.

In several respects, therefore, there was remarkable consensus about the likely causes, course and consequences of insurrection among various combinations of our commentators. Both James I and Robert Wilkinson agreed with the commons that the landed gentry of Northamptonshire had illegally enclosed their estates, and Bacon and Wilkinson were convinced that 'ingrossing' and 'great pasturages' on this scale were 
particularly pernicious to the commonwealth. Wilkinson and the diggers even rehearsed the self-same passages from Isaiah in condemning the oppression of the mighty in general and the devastating effects of enclosure in particular. Wilkinson's vilification of enclosing landlords prefigures the prosecutions that were subsequently to be launched in the Star Chamber, prosecutions which Bacon would have thought altogether unnecessary had the regime been sufficiently sensitive to pre-empt the Rising by redressing the grievances out of which it grew before they had time to take root. Although Wilkinson and the King were convinced that rebellion was self-consuming, and were at pains to deny the rebels any legitimacy in seeking to reform abuses by direct action, both implicitly conceded that the conspicuous levelling ambitions of the few concealed the genuine grievances of the many. All four of our commentators were convinced that the Crown ought to have the best interest of the commonwealth at heart, and that this commitment to paternalism should extend in particular to the punishment of enclosing landlords. One of the structural characteristics of the early Stuart state, therefore, was an implicit alliance between crown and commons, in which each was suspicious of the ability, perhaps even of the willingness, of the landed elite to enforce laws which were inimical to the interest of themselves and their networks of clientage and association. ${ }^{118}$

It is nonetheless essential to recognise the most significant divergence of opinion between our commentators. The question that caused the most controversy was whether the rebels were really hungry, and by extension whether their desperation might be taken to excuse their impatience. For the diggers, hunger was self-evident: they were 'reddy to pine for want' and despaired at the possibility of further shortage. While Bacon was prepared to concede that hunger, in the abstract, might be a fundamental cause of sedition, Wilkinson was convinced that the rural poor of Northamptonshire really had rioted out of despair. King James himself was, however, keen to deny the implication that the Rising had been provoked out of sheer necessity, and he was sceptical about popular claims about the scale, let alone the causes, of dearth. The only necessity James 
recognised, with characteristic euphemism, was that 'some blood was drawen as well by martiall Execution as by civil Justice'. ${ }^{119}$ Our dialogue therefore turns on perceptions of the causes and consequences of dearth: was shortage providential or artificial?; and could it ever justify the social theory of necessity?

\section{V: A Fifth Commentary?}

A fifth, even more famous, commentator, was also, moreover, imagining insurrection in the immediate aftermath of the Midland Rising, and both the possibility of artificial dearth and the viability of the social theory of necessity were central to his concerns. In the opening scene of Coriolanus, William Shakespeare (re-)presents a 'company of mutinous citizens' armed 'with staves clubs and other weapons' protesting about the hoarding of grain in the early days of Republican Rome. ${ }^{120}$ As several critics have noticed, however, the context for the insurrection with which Coriolanus begins deviates in significant ways from its principal source (the 1595 edition of Plutarch's 'Life of Martius Coriolanus', translated by Thomas North) to which in virtually every other respect it remains faithful. ${ }^{121}$ Shakespeare in effect conflated two historical rebellions (the usury riots which led to the creation of the tribunate in $494 \mathrm{BC}$ and the corn riots of 491BC) into a single fictional one which, like the Midland Rising, was caused fundamentally by dearth. ${ }^{122}$ In representing what was essentially an urban episode, moreover, Shakespeare makes several telling agrarian allusions. In referring to the patricians of Rome as 'gentry' or 'gentlemen', he imports, uniquely among the Roman plays, contemporary English terms of rural social description into metropolitan historical context. The play is also strewn with agricultural metaphors: Martius is compared to a 'harvest man that's task'd to mow / O'er all, or lose his hire' (1.3.36-37), for instance, and his insolence to a fire which will 'kindle' the people's 'dry stubble' (2.1.255-56). ${ }^{123}$ In describing Martius' intention to 'depopulate the city and / Be every man himself' (3.1.26465 , emphasis added), more tellingly, Shakespeare not only alludes to Isaiah v: 8 (the self- 
same passage quoted both by the diggers and by Wilkinson) but also deploys that controversial and topical verb for the only time in the entire canon. ${ }^{124}$ There is an emerging consensus, therefore, that 'most of 1.1 of Coriolanus is devoted to England's 'two troublesome years' of insurrection (1607) and dearth (1608). ${ }^{125}$

The opening scene of Coriolanus will, therefore, bear examination as Shakespeare's attempt to imagine, in light of popular familiarity with the experience of the Midland Rising, the encounter between a hungry crowd and the representatives of civic government. ${ }^{126}$ In conducting such an examination, attention necessarily focuses, first, on the opening exchange between the first and second citizens; second, on the encounter between the first citizen and the paternalist Menenius Agrippa; and third, on the contrasting attitudes towards popular insurgency of Menenius and of the military hero Martius. The following discussion reads each of these in turn to offer a more nuanced reading of Shakespeare's social and political attitudes-which have been portrayed, on the basis of this same play, either as profoundly anti-democratic ('the natural reactions of a man of substance to a recent mob rising in his country') or as highly radical (convinced 'that Jacobean England desperately needed to borrow from the strengths as well as learn from the difficulties of republican political theory'). It also seeks to demonstrate the extraordinary resonances between the text of Coriolanus 1.1 and the social and political discourses circulating in London and Northampton in $1607 .{ }^{127}$

The citizens' dialogue occurs when the first citizen calls a halt to the company's progress towards the Capitol. Their 'mutiny', like that at Newton, was only one among many simultaneous risings, for other crowds had apparently gathered elsewhere (1.1.4647). These protests, like those in Northamptonshire, had been preceded by a petition (1.1.207-11), and hunger had brought the Roman crowd, like that gathered at Newton, to the point of violence. Indeed, the Roman citizenry were convinced that they need only kill Martius, popularly regarded as 'chief enemy to the people' because of his reputation as a grain-hoarder, to have corn at [their] own price' (1.1.6-10). They are, therefore, 
sufficiently desperate to contemplate the kind of self-sacrifice (dying manfully rather than starving slowly) idealised by the Warwickshire diggers: the first citizen asks his followers whether they are 'all resolved to die rather than to famish?' (1.1.3-4). It is nonetheless significant that the crowd ultimately exercises self-control. The company does not proceed to lynch Martius as a 'very dog of the commonalty' (1.1.27-28), for after the moderate second citizen calls for restraint, his radical comrade pauses to offer a highly articulate reiteration of their grievances (1.1.14-24). The first citizen begins, in a veiled reference to the discourses of social and moral discrimination institutionalised in the Elizabethan poor laws, by pointing out that the plebs are 'accounted poor citizens'. ${ }^{28}$ Nonetheless, he insists, the excess and luxury of the patricians is such that the poor could survive merely on their surplus: 'what authority surfeits on would relieve us'. This both represents a caustic social comment on a diet so rich that even its waste possessed sufficient nutritional value for the poor and constitutes a practical proposal which recalls the compulsory direct relief in kind proposed in the late Elizabethan campaign for fasting and almsgiving. ${ }^{129}$ Bitter experience, however, has taught the first citizen that they have not been relieved so 'humanely': that little 'superfluity' which has been yielded to the poor has not been redistributed while it was 'wholesome'. Perhaps it was as rotten as the 'refuse meat, scraps and parings' condemned a few years previously by Philip Stubbes in his critique of the meagre hospitality offered by Elizabethan householders. ${ }^{130}$

The first citizen thinks, moreover, that the patricians regard the poor as 'too dear', an ironic reference to the financial calculations implicit in the charity of the rich. In a savage critique of the attitudes of the propertied towards social and economic difference, he argues that the hunger of the poor ('the leanness that afflicts us, the object of our misery') is 'an inventory' - not unlike those drawn up under the terms of the dearth orders on market regulation - to particularise [patrician] abundance'. ${ }^{131}$ The poor are going hungry precisely because the boards of the wealthy groan with excess precisely because. As the Warwickshire diggers had put it, enclosing landlords were relishing 'the 
sweetness of our wantes'. Rather than fasting in order to 'taste the dearth' out of compassion for their poorer neighbours, the wealthy were relishing a cornucopia only made possible by exploitation. ${ }^{132}$ And in pointing out that 'our sufferance' (a condition which implies both suffering and forbearance) is 'a gain to them', the first citizen discloses the reality of the situation in which the abdication of the paternal responsibilities of the elite justifies the withdrawal of deference. If the rich withhold their kindness why should the poor be patient? The first citizen therefore calls for the pragmatic of direct action: 'let us revenge this with our pikes, ere we become [thin as] rakes'. His agricultural metaphor for the symptoms of malnutrition accordingly justifies a rehearsal of the social theory of necessity which echoes that offered by Wilkinson. In an unambiguous statement of their motivation, the first citizen reminds his comrades that he speaks 'in hunger for bread, not in thirst for revenge' (1.1.21-24).

The first citizen's desperation is mocked, however, in Martius' dismissive rehearsal of the citizens' grievances. The poor argued, he disdainfully recalls, that 'hunger broke stone walls; that dogs must eat; / that meat was made for mouths; that the gods sent not / Corn for the rich men only' (1.1.205-7). For Martius, as for James I, these were merely the saws and clichés of a proverbial culture 'sigh'd forth' by an illiterate rabble (1.1.204). ${ }^{133}$ 'Shreds' (1.1.207) these proverbs may well have been, but cumulatively they constitute a resonant critique of the authorities' discourse of forbearance which had its roots in the seditious words of the hungry 1590s and was to be echoed in the petitions pleading for market regulation in the late $1640 \mathrm{~s} .{ }^{134}$ Indeed, taken together with the first citizen's critique of the logic of social and economic differentiation and with the fact that the citizens had two weeks earlier presented their grievances in a petition that very day being considered by the senate, the actions of the 'company' represented in the opening scene of Coriolanus resemble less the wild irrational fury of the 'many-headed monster' repeatedly described by Martius (2.3.15-16, 3.1.65, 82, 4.1.1-2)) than the disciplined and orderly crowd actions in defence of the moral economy 
reconstructed by Edward Thompson. ${ }^{135}$ This is not to deny that Shakespeare's Roman citizenry were hungry, rather to argue that although their hunger might not have been a sufficient cause for their mutiny, it was certainly a necessary one. After all, the principal objective of the company of citizens was to purchase corn, 'whereof they say the city is well stor'd', at what they considered to be a just price (1.1.9-10, 1.2.188-89). Indeed, their achievement was even greater than their ambition, for they subsequently succeeded in having corn distributed gratis (3.1.42) in a gesture which perfectly embodies the 'social economy of dearth'. ${ }^{136}$

Despite the range, force, coherence and sophistication of the first citizen's critique of patrician greed, the citizens' dialogue has attracted rather less critical attention than the succeeding encounter between the first citizen and Menenius Agrippa, whose paternalistic reputation as 'one that hath always loved the people' (1.1.50-51) is accepted not only by the more restrained second citizen but also by his firebrand colleague. Indeed, this meeting has been described as 'probably the most famous political confrontation in Shakespeare's works'. ${ }^{137}$ The exchange begins with Menenius offering a classic statement of paternalism. In emphasising the 'most charitable' concern (1.1.64-5) of the patricians who 'care for' the plebs 'like fathers' (1.1.76), Menenius echoes the paternalistic rhetoric of King James' proclamations in which, as we have seen, the idiom of care and compassion looms large. ${ }^{138}$ But, like both Wilkinson and King James, he emphasises the futility of attacking the immutable social and political order. In particular, he insists that dearth is providential in origin: 'the Gods not the patricians make it' (72). The first citizen is, however, contemptuously sceptical of Menenius' assessment of patrician motives: 'Care for us? True indeed! They ne'er cared for us yet' (1.1.78-79). In representing the reality of patrician attitudes, the first citizen undercuts Menenius' public transcript of paternalism. ${ }^{139}$ The patrician legislative programme owed nothing to paternalism, quite the contrary. Acts, he argues, were made 'for usury' and to 'support usurers' (1.1.80-81) (easily read as a metaphor for engrossing and engrossers), and 'more 
piercing statutes' (1.1.83) (an allusion to the settlement provisions of the poor laws and the punishments stipulated by the vagrancy acts) were passed to 'chain up and restrain the poor' (1.1.83-4). 'Any wholesome act established against the rich' (1.1.81-2) was simply repealed, just as the laws against enclosure had been suspended in 1593. Even more significantly, the first citizen denies the 'doctrine of judgements', the patrician view that dearth was providential in origin: the rich 'suffer us to famish', he insists, while 'their store-houses [are] crammed with grain' (1.1.79-80). ${ }^{140}$ This was therefore an artificial famine made by the human greed of forestallers and regrators, a view which was not only current in the ballad literature of the time; but had also been rehearsed by the commonwealthsmen of the mid-sixteenth-century; by clerical paternalists such as Archbishop Laud into the 1630s; and by petitioners complaining of 'dearth without scarcity' into the 1640s. ${ }^{141}$ In staging a debate over the causes of dearth in this way, Shakespeare was representing an exchange that was central to the discourses of early modern political economy.

The populist critique of patrician political economy becomes even more searching with the first citizen's reaction to Menenius' 'pretty tale' (1.1.89), a version of Plutarch's celebrated 'fable' in which the belly (the senate) responds to the accusations by the members (the people) that food is being deliberately withheld from them. Once again, therefore, the belly becomes a central idiom in the discourse of social justice. Menenius rehearses the organic metaphor of the body politic, emphasising the beneficial function of the stomach in particular, in order to convince the citizens of the mutual interdependence of all its members. The first citizen is sceptical even before Menenius begins, warning him against using the fable of the belly simply 'to fob off our disgrace with a tale' (1.1.93). But as the story grows in the telling, the roles of orator and audience are startlingly reversed: the first citizen interrupts Menenius seven times, asks six questions and in large measure narrates his own version of the fable himself, reducing an astonished Menenius ("Fore me, this fellow speaks!' (1.1.119)) to the status of heckler. It 
is clear that the organic metaphor is open to conflicting interpretations, especially about the respective roles of the various parts of the body, and that the first citizen is entirely capable of putting his own construction upon it. Instead of rehearsing measured rhetoric to pacify what he perceived to be an unruly mob, and thereby earning the estimation of an audience for whom rhetorical skill was one of the signifiers of gentility, an unnerved Menenius loses his cool. He first equates the Senate of Rome with the belly, arguing that it had effectively redistributed supplies throughout the body politic leaving itself only with 'the bran'; and then, arguing that the plebs simply need to 'digest things rightly touching the weal o'th'common' (1.1.149-50), immediately contradicts himself by implying that the mutinous citizens themselves constitute the belly. In so doing, he both reminds the crowd that they are hungry and compounds his error by offering them nothing but words to eat. To reassert his authority, Menenius resorts to withering satirical invective, dismissing the first citizen as the 'great toe of this assembly': the 'lowest, basest poorest' participant in this 'most wise rebellion' (1.1.154-57). Except as a cynical delaying tactic, rehearsed to buy time until Martius arrives, Menenius' belly fable is a failure (and one all the more conspicuous given that in all of the classical versions available to Shakespeare's audience it is a resounding success, representing the triumph both of poetry and of the social class that was educated enough to recite it). ${ }^{142}$ Menenius himself recognises this, ambiguously explaining to Martius that the citizens are only 'almost wholly persuaded' and conceding that 'Rome and her rats'-the plebeians ready to infest the city's granaries - 'are at the point of battle; the one side must have bale' (i.e. sorrow, pain, misfortune) (1.1.161-62). ${ }^{143}$ Most significantly of all, the first citizen is himself obviously unpersuaded by the metaphor: for him the senate is simply the 'sink', or sewer, of the body politic — nothing but a 'cormorant belly' (1.1.120-21).

This analogy with the double-stomached cormorant, a bird renowned for its greed and a proverbial figure for an insatiably covetous or rapacious person, was apposite. ${ }^{144}$ This term of opprobrium had become commonplace among early humanists 
such as Thomas Elyot and commonwealthsmen such as Robert Crowley and Thomas Becon. It had more recently been widely deployed in the late Elizabethan campaign against those engrossers who were trying to corner the market in grain, described by the author of the Three Sermons on almsgiving in 1596 'as greedy cormorants, I should have said cornemaisters'; and in a privy council circular of September 1597 as 'more lyke to wolves or cormerants then to natural men'. ${ }^{145}$ It also loomed large in subsequent analyses of the causes of the rising. In 1623, the Leicestershire clergyman John Brinsley explained the 'levellers' insurrection' as a consequence of the actions of 'all those who had gathered up any wealth', who had 'generally become cormorants to swallow up the poor'. 'Have we not growne to this height of unsociable covetousness and unmercifulness', he asked, that we have had these 'cormorants to catch up all of a sudden at any rate?'. ${ }^{146}$

Indeed, the greed of the Roman senate is nowhere more vividly disclosed than in Menenius' attempted joke, twisting the sagging flesh of his full belly to make it 'smile' and 'speak' - to belch?, perhaps even to fart? (1.1.109-9). By advertising his difficulty in digesting the plenty that was available to him at the very same time as he was trying to convince the citizens that the senators had distributed all the flour and left nothing for themselves, Menenius inadvertently reveals the rehearsal of the belly fable to be a selfserving act of hypocrisy. It also invites a retrospective literal reading of the first citizen's earlier reference to the possibility of surviving on the waste products of the patrician digestive system (1.1.15). Like Bacon and Wilkinson, therefore, Shakespeare uses the belly as a central metaphor to discuss the most appropriate distribution of resources in a profoundly unequal society.

In Martius' own social attitudes towards civil commotion, finally, we hear echoes of the punitive policy advocated by the Crown, and administered by the Lords Lieutenant of Leicestershire and Northamptonshire in the immediate aftermath of the Midland Rising. Martius is profoundly sceptical about the citizens' grievances, dismissing their petition as 'strange' (1.1.209). Indeed, like King James he refuses to 
accept that they are hungry, and in his invective against the 'rank-scented' (3.1.65) multitude, bids them 'keep their teeth clean' (2.3.63), a practical suggestion to cure their halitosis but also an ironic allusion to the scriptural metaphor for starvation ('cleanness of teeth') deployed in debates about poor relief and market regulation from the 1590s to the 1640s. ${ }^{147}$ Martius is, accordingly, furious that the 'rabble' (1.1.217) have been granted concessions, not least because, like Wilkinson, he can envisage the Rising as a selfradicalising process: the citizens 'will in time / Win upon power, and throw forth greater themes / For insurrections arguing' (1.1.218-20). In 'soothing' the citizens, he argues, 'we nourish 'gainst our senate / The cockle of rebellion', but tellingly concedes, by the use of a revealing agricultural metaphor, that the senate has itself 'sow'd and scatter'd' the seeds of 'insolence and sedition' (3.1.68-70). Similarly, in dismissing the citizens as 'fragments' (1.1.221), he both expresses his contempt for organic understandings of the social order, and in the process of comparing them to remnants, reminds the hungry crowd of scraps of uneaten food with which many thousands might be fed. ${ }^{148}$ His policy is, nonetheless, one of retribution. Indeed, retribution is Martius' watch-word, for he repeatedly exclaims that the citizens should be hanged $(1.1 .189,203)$, echoing, in the call for a gibbet (and even for mock executions), the policy adopted by the earl of Huntingdon in the environs of Leicester during the Rising. ${ }^{149}$ In noting that the protesters on the other side of the city 'are dissolved' (1.1.203), his passive construction and use of euphemism invites imaginative speculation about the awful nature of the punishment which has been meted out. ${ }^{150}$ And in pleading with the patricians to 'let me use my sword' and 'make a quarry / with thousands of these quarter'd slaves, as high / as I could pick my lance' (1.1.197-99), Martius conjures up horrifying images of the gibbeted carcases of slain traitors, envisaging a 'harvest of heads' of the kind exhibited in the towns of Northamptonshire in the summer of $1607 .{ }^{151}$ Elsewhere, Martius' invective echoes not only Wilkinson's fear of popular levelling but also King James' policy of retribution: in arguing that the Roman citizenry will 'lay the city flat / to bring the roof to 
the foundation, / and bury all which distinctly ranges / in heaps and piles of ruin' (3.1.201-4), he endorses the rhetoric of the proclamation in which James had predicted that insurrection would by its very nature bring 'a heape of calamities upon multitudes of innocent Subjects'. ${ }^{152}$

\section{VI: Conclusion}

It is not the purpose of this argument to imply that Shakespeare could have written 1.1 of Coriolanus only after he read either Bacon's 'Of Seditions and Troubles' or Robert Wilkinson's Sermon Preached at Northampton (though both, especially the latter, are genuine possibilities); still less to endorse the view that the full version of Bacon's essay, published in 1625, may well have been revised in the light of the appearance of the first folio of the play in $1623 .{ }^{153}$ The parallels and convergences between the social and political attitudes rehearsed in Coriolanus and those current in the discourses surrounding the Midland Rising are nonetheless striking. In seeking to persuade the citizens that the patricians have their best interests at heart, Menenius seems to be fulfilling Bacon's objective of securing 'the good Will of Common People' (11.174-75), even if that meant 'the Politique and Artificiall Nourishing, and Entertaining of hopes' (11.185-6). In demonstrating the political risks associated with conferring power on a military hero who has no ear for the grievances of the people, Shakespeare stages the terrible consequences of the martial suppression of insurrection by a 'military person' who did not hold 'good Correspondence, with the other Great Men in the State'. In Bacon's terms, Martius might be 'the Remedie' for a rising of the people but he proved to be 'worse than the Disease' (11.237-40). In denying the reality of plebeian hunger, Martius echoes the scepticism of a monarch unconvinced that commotion had been provoked by the law of necessity.

Whatever the play may or may not reveal about Shakespeare's own attitudes, his familiarity with the idioms associated with the political economy of grain supply suggest that Coriolanus is no less valuable a source than the digger Broadside, King James' 
proclamations, Wilkinson's Sermon or Bacon's essay for historians seeking to understand the dynamics of popular protest in the early seventeenth century. The play not only echoes and rehearses the discourses associated with the Midland Rising, but explores the parameters of what it was possible to think about hunger, about paternalism, about protest and about punishment in Jacobean England. Nowhere is this more evident than in the exchange between Menenius and the first citizen over the fable of the belly. Indeed, the belly was a central metaphor for all the protagonists in the imaginary dialogue rehearsed here, as it was for many other contemporaries who were outraged at hunger and the covetousness which caused it. In his remarkable tirade against the exploitation of the workforce in the textile industry, for instance, Thomas Carew preached in 1603 that 'the bellies of the poore are in the barnes of the rich'; and East Anglian cloth-workers themselves bitterly complained that 'words would not fill the belly nor clothe the backe' during the crisis of $1629 .{ }^{154}$

The remarkable concentration of allusions to grumbling stomachs among those commenting on the Midland Rising is nonetheless striking. For the starving diggers of Warwickshire, the belly was quite literally empty: only the voracious 'devouring encroachers' and their sheep were actually eating now; and in the near future mothers would be driven to eat their own children. For James I, however, hunger was a condition to be ignored, perhaps even denied, as the mis-diagnosed product of a visceral ulcer which must be excised from the body politic. For Robert Wilkinson and Francis Bacon, however, the metaphor was more resonant still. Wilkinson knew that empty bellies might compel the hungry poor to civil commotion, however insistent the authorities' prescription of patience. Bacon, familiar as he was with an extraordinary range of seditions and troubles, thought the 'rebellions of the belly' to be 'the worst'. When, in 1608, Shakespeare imagined the attempt to appease the hungry citizenry of Republican Rome, he had Plutarch to thank for Menenius' rehearsal of the fable of the belly. But he was as finely attuned to the idiom of the common people as to the rhetoric of classical 
antiquity. Precisely because he knew his audience was so familiar with the proverbial wisdom (so recently rehearsed in Wilkinson's Sermon) that 'the belly has no eares', he was able to undercut Plutarch's confident reading of the effect of Menenius' oratory. Shakespeare's representation of the fable, therefore, suggests some sympathy with the grievances of the poorer sort who were expected to be satisfied merely by the rehearsal of paternalistic rhetoric. As Wilkinson had argued, plebeian want was not 'well digested', least of all when confronted with Menenius Agrippa, the living symbol of a 'cormorant belly', a parasite devouring the body politic from within.

There are, of course, numerous other lenses through which Coriolanus might be read. ${ }^{155}$ But one of its most prominent themes is arguably that of the most appropriate action a regime might take when confronted with the grievances of its citizens. Although King James had been concerned to argue that concessions had not been granted to 'satisfie disobedient people be they rich or poore', Martius is unpersuaded: he tells Menenius that the free distribution of corn merely 'norissh'd disobedience and fed the ruin of the state' (3.1.116-17), allowing 'the rabble [to] call our cares fears' (3.1.135-6). Above all, in allowing the first citizen to rehearse so effectively the grievances of the hungry citizenry, Shakespeare ventilates the social and political attitudes of the poorer sort with a clarity and conviction which echoes the moral outrage of the digger broadside. What is staged in the first scene of Coriolanus resembles less the violent insurrection envisaged by Martius than the orderly, disciplined encounter between the diggers and the Warwickshire magistracy described by the earl of Shrewsbury. ${ }^{156}$ Indeed, it is arguable that 1.1 of Coriolanus imagines not insurrection itself but the prevention of insurrection by the timely redress of grievances, a policy subsequently endorsed by Francis Bacon and conspicuous by its absence from the counsels of James I in 1607, at least until the crown's hand had been forced by civil commotion.

It would not be long, moreover, before readers could begin to make these connections, comparisons and contrasts for themselves. Indeed, by the end of the 
seventeenth century (and perhaps even earlier), a popular collective reading of the discourses analysed here was not entirely beyond the realms of possibility. King James' proclamations would have been read from the pulpit, and subsequently nailed to church doors and market crosses, ensuring that they were discussed and debated in churchyard and town square alike. Although Wilkinson's sermon enjoyed only a relatively small auditory when it was first preached at Northampton in June 1607, within a few weeks it was entered into the Stationers' Company register and by the end of the year was being printed and sold to a metropolitan and provincial audience that quite possibly included both Bacon (who may or may not have been present in Northampton to hear Wilkinson deliver it) and Shakespeare. It is not difficult to imagine, furthermore, that Wilkinson, Shakespeare and perhaps even James I himself saw, or heard quoted, the digger broadside, itself already circulated and remembered in the popular culture of the day. Coriolanus was almost certainly first performed at Blackfriars in the summer of 1608 , and remarkably enough seems to have escaped the attentions of a censor who had required cuts in previous attempts, by Shakespeare and by others, to dramatise insurrection. ${ }^{157}$ Within a decade or so, the first Folio edition of his works was in print and a still wider public audience could hear the first citizen eloquently critiquing inequalities of wealth and power. Even Bacon's 'Of Seditions and Troubles' was not long restricted to a select group of readers. Although it remained unpublished until 1625, it was by the end of the seventeenth century being disseminated in popular almanacs, the archetypal mass media of the day. ${ }^{158}$ These were not the only texts, of course, through which a seventeenthcentury readership might imagine the dynamics of insurrection, but in their common store of reference to and experience of the Midland Rising, they disclose a remarkable consensus about the appropriate obligations of rulers and ruled. To be sure, as John Walter's seminal essays have been demonstrating since the 1980s, rulers and ruled in seventeenth-century England were caught in a field of force of paternalism and deference. ${ }^{159}$ These obligations were, however, as Edward Thompson suggested for the 
patricians and plebs of the eighteenth century, not only highly theatrical but reciprocal and conditional. ${ }^{160}$ When the masks of paternalism and deference slipped, the countertheatre of social relations was characterised by the class-based antagonism more characteristic of Andy Wood's reading of popular politics. ${ }^{161}$ At a time of commotion, then, the politics of paternalism and deference was subordinated to a politics of fear and hatred, in which the poor condemned their rulers as 'merciless men' who rejected their sincere appeals first with contempt and ultimately with armed force; and the authorities feared that 'every vile and base companion' would be king. ${ }^{162}$

What, finally, does a study of representations of the Midland Rising disclose about the dynamics of insurrection that could not have been learned from a more orthodox social-historical analysis of the episode? To be sure, the currently fashionable social-distributional approach to the history of popular protest has permitted ever more finely-grained analysis of the social profile of participation; of the loops of association which bound protesters together; and of the proximate structuration of class relationships which influenced highly-localised patterns of solidarity and stratification. ${ }^{163}$ At the same time, however, the proliferation of case-studies of individual riots and risings only serves to obscure several significant elements which were central to the concerns of contemporaries. Many of these have emerged during the foregoing discussion of the ways in which contemporaries represented the Midland Rising: the significance of labelling specific social groups (protesters as a rabble of 'levellers', 'diggers' or 'fragments'; enclosing landowners and grain-hoarders as 'wolvish lords', 'devouring encroachers' or 'cormorants'); the centrality of the idioms of scripture and of proverbial culture to the rhetoric of social justice (the grinding of the faces of the poor, the depopulating landlord dwelling alone in fields full only of sheep, the view that necessity knew no law); the widespread relief that rebellion was a self-radicalising process, a creeping conspiracy which rebels themselves could not control even if it ultimately destroyed them; and the perception of class antagonism (mechanical men bearding magistrates, the vile 
presuming against the honourable, a mutinous citizenry dismissing elite paternalism as a gesture politics borne of cynicism or fear).

Most obviously, however, in their sustained use of a metaphorical idiom in which politic bodies and empty bellies loomed large, contemporaries discussed the politics of subsistence with a vehemence rendered almost inaudible in the flurry of price series and mortality rates analysed by modern historians. After all, hunger was not merely a figure of speech but a lived experience for substantial numbers of people in the early seventeenth-century. It was apparently another half-century before England 'slipped the shadow of famine'. ${ }^{164}$ The consequences of going hungry are, nonetheless, painfully apparent in the early seventeenth-century registers of midland parishes. Although burials soared in the Warwickshire Arden during the dearth years of 1606-7, the median term demographic consequences of agrarian change were no less awful. ${ }^{165}$ By the 1610s, falling rates of marriage and of age-specific marital fertility (especially among poorer families); and increasing rates of infant mortality, of maternal morbidity, and of pauper burial suggest that the recently enclosed communities of the Midlands were experiencing an endemic food shortage leading to creeping malnutrition. ${ }^{166}$ The Warwickshire diggers had foreseen that the hedging of the common fields of the Midlands was likely to result in a lingering death for themselves and their families. And like Shakespeare's hungry citizenry, they resolved that they would not to starve to death quietly-and 'stood up about the corn' $(3 \cdot 2 \cdot 15-16){ }^{167}$ 


\section{HINDLE: 'Imagining Insurrection'/Endnotes}

* This paper was first delivered to seminars at the Universities of Birmingham (Shakespeare Institute), London (Institute of Historical Research), Nottingham and Oxford. I am grateful to the audiences for their helpful comments and questions on those occasions. My thinking about Coriolanus was sharpened by an invitation to discuss the social and economic context of the play's composition with the company rehearsing Gregory Doran's 2007 RSC production. I am grateful to the many friends and colleagues who were kind enough to read early drafts; and for the suggestions of anonymous referees. Any errors that remain are my own.

${ }^{1}$ The following account is drawn, except where noted, from the letter sent by Gilbert Talbot, earl of Shrewsbury to Sir John Manners, Sir Francis Leake and Sir John Harper from Whitehall, 11 June 1607, printed in John Nichols, The History . . of the County of Leicester, 4 vols, London, 1795-1815, vol.iv, p.83 and quoted more accessibly in Edwin F. Gay, 'The Midland Revolt and the Inquisitions of Depopulation of 1607', Transactions of the Royal Historical Society, new ser. 18, 1905, pp.216-17n.

${ }^{2}$ British Library, London (hereafter BL), MS Lansdowne, 90/23 (earl of Shrewsbury to the earl of Kent, 2 June 1607). John Gurney, Brave Community: The digger Movement in the English Revolution, Manchester, 2007, pp.123, 144 n.122 notes that when the London press first referred to Gerrard Winstanley's followers as 'diggers' in April 1649, they may well have had in mind the precedent of 1607. The ideas associated with levelling, however, go back to the fourteenth century at least. For a suggestive survey, which curiously makes no reference to the Newton episode, see Christopher Hill, 'From Lollards to Levellers', reprinted in The Collected Essays of Christopher Hill, Volume II: Religion and Politics in Seventeenth Century England, Brighton, 1986, pp.89-116. Even though several early-seventeenth commentators, including James I, 'Speech in the Star Chamber, 1616', in Charles H. McIlwain (ed.) The Political Works of James I, New York, 1965 , p.344, subsequently referred to the 1607 rising as a 'levellers' insurrection, the first 
analyst of the Leveller movement seemed unaware of the pre-history of the term: see Marchmont Nedham, The Case of the Commonwealth of England Stated (London, 1650), pp.69-79.

${ }^{3}$ This was James I's own assessment. J.F. Larkin and P.L. Hughes (eds) Stuart Royal Proclamations, volume I: Royal Proclamations of King James I, 1603-1625, Oxford, 1973, p.158.

${ }^{4}$ For Montagu and Mildmay, see Esther S. Cope, The Life of a Public Man: Edward, First Baron Montagu of Boughton, 1562-1644, Philadelphia, 1981; and Richard Cust, 'Edward Montagu, First Baron Montagu of Boughton (1562/3-1644)' and L.L. Ford, 'Sir Anthony Mildmay (c.1549-1617), both in Oxford Dictionary of National Biography, Oxford, 2004 [hereafter $O D N B]$.

${ }^{5}$ Cope, Life of a Public Man, p.51. That the crowds which gathered at the sites of the Midland Rising remained for several days before they were dispersed suggests continuity with the tradition of rebel 'camps' established during the 'commotion tyme' of 1549. Amanda Jones, “'Commotion Time”: The English Risings of 1549', Unpublished PhD Dissertation, University of Warwick, 2003, pp.4 (\& map 1.2), 90-3, 169-74, 210-15; and Andy Wood, The 1549 Rebellions and the Making of Early Modern England, Cambridge, 2007, pp.47-55.

${ }^{6}$ H.F. Brown (ed.), Calendar of State Papers, Venetian, vol. XI, 1607-10, London, 1904, p.8 (26 June 1607) notes that the Newton levellers had been 'terrified by the death of some of their leaders, who were captured and hung in their sight'. The site of the battle, popularly known as Newton-field, was almost certainly The Brand, an area of waste in Rockingham Forest in which the villagers of Geddington, Stanion, Brigstock and Little Oakley had once inter-commoned and which Thomas Tresham had illegally enclosed in the late sixteenth-century. Burl Bellamy, Geddington Chase: the History of a Wood, Irthlingborough, 1986, pp.38-43; Glenn Foard and Tracey Partida, A Legacy of Kings: The Story of Rockingham Forest, Oundle, 2005, p.27; and cf. Nicola Whyte, 'Landscape, 
Memory and Custom: Parish Identities, c. 1550-1700', Social History 32:2, May 2007, $166-$ 67, 176-77, 185-86.

${ }^{7}$ Thomas Cox, rector of Great Addington (Northants.), quoted in Peter Whalley, The History and Antiquities of Northamptonshire, 2 vols, Oxford, 1791, vol.ii, p.206. Cf. Northamptonshire Notes and Queries i (1886), no.62.

${ }^{8}$ Cope, The Life of a Public Man, p.51. John Walter, 'Hidden Transcripts and the Politics of Sedition in Early Modern England: A Lincolnshire Libel "The Pooremans Joy and the Gentlemans Plague", Unpublished Paper, 2006, offers a brilliant analysis of one particular rumour.

${ }^{9}$ The two most recent accounts are John E. Martin, Feudalism to Capitalism: Peasant and Landlord in English Agrarian Development, London, 1983, pp.159-215; and Roger B. Manning, Village Revolts: Social Protest and Popular Disturbances in England 1509-1640, Oxford, 1988, pp.229-46, both of which use the term 'Midland Revolt'.

${ }^{10}$ For a recent synthesis, see Keith Wrightson, Earthly Necessities: Economic Lives in Early Modern Britain, New Haven, 2000, pp.159-201.

${ }^{11}$ Joan Thirsk, 'Enclosing and Engrossing', in Joan Thirsk (ed.), The Agrarian History of England and Wales, volume IV: 1500-1640, Cambridge, 1967, p.228. The debates surrounding the restoration (in 1597) and continuation (in 1601) of the tillage laws, accessibly reprinted in T.E Hartley (ed.), Proceedings in the Parliaments of Elizabeth I, 3 vols, Leicester, 1995, vol.iii, pp.215-24, 230-31, are skilfully rehearsed in Andrew McRae, God Speed the Plough: The Representation of Agrarian England, 1500-1660, Cambridge, 1996, pp.712.

${ }^{12}$ Martin, Feudalism to Capitalism, pp.180-91; John Goodacre, The Transformation of a Peasant Economy: Townspeople and Villagers in the Lutterworth Area, 1500-1700, Aldershot, 1994, pp.93-106. The best case-study of the impact of enclosure in the midlands at this time remains L.A. Parker, 'The Agrarian Revolution at Cotesbach, 1501-1612', Transactions of the Leicestershire Archaeological Society 24, 1948, pp.41-76. 
${ }^{13}$ Thomas Tresham of Newton had been flouting laws and proclamations against enclosure for at least a generation. As early as 1564 , long before the tillage laws were suspended, there were 650 sheep grazing in Newton. By 1597-98, Tresham was being prosecuted in the Star Chamber for depopulation and sheep farming. By 1607, the whole parish was under grass and had been leased out to graziers, probably having been completely enclosed in the mid-1590s. In about 1599, Tresham had also purchased the estate at Pilton from his cousin, the equally notorious enclosing landlord Sir Thomas Tresham of Rushton, and destroyed five farms in the process of converting 135 acres of arable to sheep pasture. Manning, Village Revolts, p.240. For significant sheep-flocks elsewhere in the county, see John E. Martin, 'Sheep and Enclosure in Sixteenth-Century Northamptonshire', Agricultural History Review 36:1, Spring 1988, pp.39-45.

${ }^{14}$ Cf. Steve Hindle, 'Persuasion and Protest in the Caddington Common Enclosure Dispute, 1635-39', Past and Present no.158, February 1998, pp.37-78

${ }^{15}$ Cf. Jones, "“Commotion Time”"; Wood, 1549 Rebellions.

${ }^{16}$ The classic statements are Mervyn E. James, 'The Concept of Order and the Northern Rising, 1569', 'English Politics and the Concept of Honour, 1485-1642', and 'At a Crossroads of the Political Culture: The Essex Revolt, 1601', all (reprinted) in James, Society, Politics and Culture: Studies in Early Modern England, Oxford, 1986, pp.270-307, 308-415, 416-65; and John Walter, 'A "Rising of the People"? The Oxfordshire Rising of 1596', reprinted in Walter, Crowds and Popular Politics in Early Modern England, Manchester, 2006, esp. pp.102-6. These analyses underpin the discussion in Anthony Fletcher and Diarmaid MacCulloch, Tudor Rebellions, $5^{\text {th }}$ edn, Harlow, 2004, pp.135-38.

${ }^{17}$ Walter, 'A "Rising of the People"?, p.104.

${ }^{18}$ Cf. John Morrill, 'William Brereton and England's Wars of Religion', Journal of British Studies 24, 1985, p.323.

${ }^{19}$ For Robert Wilkinson's dismissive reference to John Reynolds as a tinker, see p.17 [text at n.72] below. 
${ }^{20}$ David Levine and Keith Wrightson, The Making of an Industrial Society: Whickham, 15601765, Oxford, 1991, p.348; Michael J. Braddick and John Walter, 'Introduction. Grids of Power: Order, Hierarchy and Subordination in Early Modern Society', in Michael J. Braddick and John Walter (eds), Negotiating Power: Order, Hierarchy and Subordination in Early Modern England and Ireland, Cambridge, 2001, p.42.

${ }^{21}$ Andy Wood, 'Subordination, Solidarity and the Limits of Popular Agency in a Yorkshire Valley, c.1596-1615', Past and Present no.193, November 2006, pp.41-72.

${ }^{22}$ The operative law was 1 James I, c.25 (1604), which re-enacted the last Elizabethan tillage statute of 1601 .

${ }^{23}$ For this idiom, see John Walter, Understanding Popular Violence in the English Revolution: The Colchester Plunderers, Cambridge, 1999, p.284. Cf. the earlier assessment of Shannon Miller, 'Topicality and Subversion in William Shakespeare's Coriolanus', Studies in English Literature, 1500-1900 32:2, 1992, p.302 that 'an enemy of the people, of the commons, is actually an enemy to the state'.

${ }^{24}$ For the symbolic and material significance of hedges, see Nicholas Blomley, 'Making Private Property: Enclosure, Common Right and the Work of Hedges', Rural History 18, April 2007, pp.1-21.

${ }^{25}$ John Walter, 'Crown and Crowd: Popular Culture and Popular Protest in Early Modern England', reprinted in Walter, Crowds and Popular Politics, pp.14-26. Cf. Ethan H. Shagan, 'Protector Somerset and the 1549 Rebellions: New Sources and New Perspectives', English Historical Review 114, 1999, pp.34-63; and the restatement of this position in Shagan, 'Protector Somerset and the 1549 Rebellions: Popularity and the 1549 Rebellions Revisited', English Historical Review 115, 2000, pp.121-33. For the 1549 rebels as 'commotionars', see Robert Crowley, 'One and Thyrtye Epigrammes' [1550], in J.M. Cowper (ed.), The Select Works of Robert Crowley, Early English Text Soc., extra ser. 15,1872, pp.21-23. 
${ }^{26}$ Mary Dewar (ed.), A Discourse of the Commonweal of This Realm of England, Attributed to Sir Thomas Smith, Charlottesville, 1969. For Smith's 'new moral philosophy', see Neal Wood, Foundations of Political Economy: Some Early Tudor Views on State and Society, Berkeley, 1994, pp.191-235 (and pp.205-6 in particular for the significance of the dialogic form of the Discourse).

27 'The True Information of the Entertainment of his Royal Majesty' (1603), in C.H. Firth (ed.), Stuart Tracts, London, 1903, pp.40, 42; Historical Manuscripts Commission, Report on the Manuscripts of Lord Montagu of Beaulieu, London, 1900, p.42.

${ }^{28}$ British Library, London, (hereafter BL), MS Harley, 787/11; Hughes and Larkin (eds), Stuart Royal Proclamations, vol. I, p.154. For the tradition of libelling and its medieval antecedents, see Adam Fox, Oral and Literate Culture in Early Modern England, Oxford, 2000, pp.299-35; and Wendy Scase, "'Strange and Wonderful Bills": Bill-Casting and Political Discourse in Late Medieval England', in Rita Copeland, David Lawton and Wendy Scase (eds), New Medieval Literatures 2, Oxford, 1998, pp.225-47.

${ }^{29}$ The National Archives, Public Record Office, Kew (hereafter TNA: PRO), STAC8/205/19; Fox, Oral and Literate Culture, p.332.

${ }^{30}$ Except where noted, the following discussion is indebted to John Walter, 'John Reynolds [Captain Pouch] (d. 1607)', ODNB.

31 TNA: PRO, STAC8/221/1 (Bill of complaint of Sir John Newdigate of Arbury, Warwicks., 3 May 1608).

${ }^{32}$ The earl of Huntingdon thought Reynolds the "chiefest leader and director of the rebellious company' and the privy council referred to him as 'that base ringleader and turbulent varlet' (the latter term connoting both rogue or rascal and, by conventional association, 'scribbler': OED). Historical Manuscripts Commission, Report on the Manuscripts of the late Reginald Rawdon Hastings, Esq., of the Manor house, Ashby de la Zouche, 4 vols, London, 1928-47, vol.iv, p.193 (earl of Huntington to Robert Cecil, 6 June 1607), 194 (PC to the earl of Huntingdon, 9 June 1607). 
${ }^{33}$ John Stow, Annales, or a General Chronicle of England, cont. Edmund Howes, London, 1615 edn, p.889.

${ }^{34}$ Walter, 'A “Rising of the People”?', pp.76, 78, 79-81. Cf. C. Ginzburg, The Cheese and the Worms: The Cosmos of a Sixteenth Century Miller, London, 1980, p.xxi.

${ }^{35}$ The famine of 1315-22 evidently had considerable resonance in popular memory. See William Gouge, God's Three Arrowes: Plague, Famine Sword, In Three Treatises (London, 1631), pp.170-71, for a very similar report of cannibalism in the aftermath of early fourteenth-century harvest failure. Cf. W.C. Jordan, The Great Famine: Northern Europe in the Early Fourteenth Century, Princeton, 1996.

${ }^{36} \mathrm{Cf}$. the view that 'rather then they would be starved', 'poore men' would 'ryse'. Walter, 'A "Rising of the People"?', p.78. For the endurance of the idiom that the hungry would rather hang than starve, see John Bohstedt, Provision Politics: Bread Riots, Moral Economy and English Market Society, 1527-1867 and Beyond, Aldershot, forthcoming, ch. 4.

${ }^{37}$ John Walter and Keith Wrightson, 'Dearth and the Social Order in Early Modern England', Past and Present no.71, February 1976, p.30. The local proverbial association of depopulating enclosure with dearth can be traced back at least as far as Certayne Causes Gathered Together, Wherein is Shewed the Decay of England, Only by the Great Multitude of Shepe, London, 1552, an anonymous treatise whose argument is based on anecdotal evidence from the midland counties of Buckinghamshire, Northamptonshire and Oxfordshire, here quoting sigs. $\mathrm{A} 3^{\mathrm{r}}, \mathrm{A} 4^{\mathrm{r}}-4^{\mathrm{v}}$.

${ }^{38}$ BL, MS Lansdowne, 90/23.

${ }^{39}$ TNA: PRO, SP16/307/2 (and cf. J. Bruce (ed.), Calendar of State Papers, Domestic, vol. IX, 1635-36, London, 1866, p.22, where it is erroneously dated to [?]1635). This important document, written after the 'pacifacon' of the 'trobles', is only very obliquely discussed in existing studies of the Rising: Gay, The Midland Revolt', p.214n.1; Martin, Feudalism to Capitalism, p.212 \& n.63 [p.244]; and Manning, Village Revolts, p.241 (which cites only the calendared version). 
${ }^{40}$ For the 'uses of waste', see Jeanette M. Neeson, Commoners: Common Right, Enclosure and Social Change in England, 1700-1820, Cambridge, 1993, pp.158-84; and Donald Woodward, 'Straw, Bracken and the Wicklow Whale: The Exploitation of Natural Resources in England since 1500', Past and Present no.159, February 1998, esp. pp.48-56. It is more likely, however, that the loss of common fields, rather than common wastes, was felt particularly acutely in this part of the Midlands. Goodacre, Transformation of a Peasant Economy, pp.129-41.

${ }^{41}$ TNA: PRO, SP14/34/4, William Combe, Sheriff of Warwickshire, to Robert Cecil, from Warwick, 2 June 1608. Tellingly, Combe regarded the popular association of dearth with enclosure as both arrogant and seditious.

${ }^{42}$ Edward Arber (ed), A Transcript of the Registers of the Company of Stationers of London 1554-1640 A.D., 5 Volumes, London, 1875-94, vol.III, p.394 (12 Nov. 1608); Hyder E. Rollins, (ed.), An Analytical Index to the Ballad-entries (1557-1709) in the Registers of the Company of Stationers of London, Hatboro, Pa., 1967, pp.75 (no.812), 116 (no.1340).

${ }^{43}$ Hughes and Larkin (eds), Stuart Royal Proclamations, vol. I, p.161; Arthur Standish, The Commons Complaint, London, 1611, sig.B2 ${ }^{v}$ (Standish was quite probably connected with the Northamptonshire gentry, had been deeply troubled by the Rising and his treatise was the product of four years' research into measures which might diminish discontent amongst the poor); John Moore, A Target for Tillage, London, 1612, sig.B1 ${ }^{\mathrm{v}}$ (Moore was rector of Knaptoft, Leics., and his pamphlet was probably the second edition of an earlier lost text, written in the immediate aftermath of the Rising).

${ }^{44}$ Martin, Feudalism to Capitalism, pp.180-215.

${ }^{45}$ Stephen Hipkin, “'Sitting on his Penny Rent': Conflict and Right of Common in Faversham Blean, 1595-1610', Rural History 11, April 2000, p.23.

${ }^{46}$ CSPV, 1607-1610, p.8 (26 June 1607).

${ }^{47}$ Hughes and Larkin (eds), Stuart Royal Proclamations, vol. I, pp.152-4 [no.71], 154-58 [no.72], 61-62 [no.74]. 
${ }^{48} \mathrm{HMC}$, Report on the Manuscripts of the Duke of Buccleuch and Queensberry preserved at Montagu House, Whitehall, Volume 3, London, 1926, p.116; HMC, Calendar of the Manuscripts of the Most Honourable the Marquess of Salisbury, preserved at Hatfield House, Hertfordshire. Pt.20, (A.D. 1608), London, 1968, p.87 (28 Feb. 1608).

${ }^{49}$ Wallace Notestein, Francis Helen Relf and Hartley Simpson (eds), Commons Debates 1621, 7 vols, New Haven, 1935, vol.iv, p.71.

${ }^{50}$ The proclamation was designed to reinforce privy council instructions of 29 May to the justices of Gloucestershire, Huntingdonshire, Leicestershire and Worcestershire to suppress gatherings against enclosure. BL, MS Additional, 11402, fol.127.

${ }^{51}$ Hughes and Larkin (eds), Stuart Royal Proclamations, vol. I, p.153.

${ }^{52}$ Hughes and Larkin (eds), Stuart Royal Proclamations, vol. I, p.156.

${ }^{53}$ Stow, Annales, p.889. It is striking that the charge should refer to 'throwing down hedges', in a curious inversion of the diggers' claims that depopulating landlords 'threw down' houses.

${ }^{54}$ W.P. Baildon (ed.), Les Reportes del Cases in Camera Stellata, 1593 to 1609, from the Original MS of John Hawarde, London, 1894, p.413.

55 'A Consideration of the Cause in Question Before the Lords Touching Depopulation, 5 July 1607', printed in J. Thirsk and J.P. Cooper (eds), Seventeenth-Century Economic Documents, Oxford, 1972, p.107.

${ }^{56}$ Hughes and Larkin (eds), Stuart Royal Proclamations, vol. I, p.157.

${ }^{57}$ Thirsk, 'Enclosing and Engrossing', p.242. For the debate on the reliability of the returns, see Eric Kerridge, 'The Returns of the Inquisitions of Depopulation', English Historical Review 70, 1955, pp.212-28; John E. Martin, 'Enclosure and the Inquisitions of 1607: An Examination of Dr Kerridge's Article 'The Return of the Inquisitions of Depopulation', Agricultural History Review 30, Spring 1982, pp.41-48.

${ }^{58}$ Manning, Village Revolts, pp.249-50.

${ }^{59}$ Martin, Feudalism to Capitalism, p.185. 
${ }^{60}$ On the financial and political advantages of pardoning rebels, see Krista J. Kesselring, 'Mercy and Liberality: The Aftermath of the 1569 Northern Rebellion', History no.298, April 2005, pp.213-35; Kesselring, The Northern Rebellion of 1569: Faith, Politics and Protest in Elizabethan England, Basingstoke, 2007, pp.126-36.

${ }^{61}$ Hughes and Larkin (eds), Stuart Royal Proclamations, vol. I, p.161.

${ }^{62}$ Hughes and Larkin (eds), Stuart Royal Proclamations, vol. I, p.161. For the wider significance of this trope, see Steven Mullaney, "'Lying Like Truth": Riddle, Representation and Treason in Renaissance England', English Literary History 47, 1980, pp.32-47.

${ }^{63}$ V.H.T Skipp, Crisis and Development: An Ecological Case Study of the Forest of Arden, 15701674, Cambridge, 1978, p.37.

${ }^{64}$ P. Bowden, 'Statistical appendix', in Thirsk (ed.), Agrarian History, p.820; Orders Appointed by His Majestie to be Straightly Observed for the Preventing and Remedying of Dearth of Graine and Other Victual (London, 1608) [RSTC 9217]; Paul Slack, 'Dearth and Social Policy in Early Modern England', Social History of Medicine 5, 1992, p.2 n.2. A convenient modern edition of the full text of the 1608 orders is provided in T. Gray (ed.), Harvest Failure in Cornwall and Devon: The Book of Orders and the Corn Surveys of 1623 and 1630-31 (Institute of Cornish Studies, Sources of Cornish Hist., 1, Plymouth, 1992), pp.92-102. For the subsequent royal proclamation of 12 December 1608 'touching maulsters, common-brewers and Alehouse-keepers', see Stuart Royal Proclamations, vol. I, pp.200-202 [no.91]. The best evidence for the enforcement of the 1608 dearth orders originates in the borough records of Sandwich (Kent). Kent Archives Office, Maidstone, Sa/ZB/3/8-14 (Papers dealing with the shortage of grain in Sandwich and in particular surveying the quantities in the town and the names of the persons holding it, 1608).

${ }^{65}$ Hughes and Larkin (eds), Stuart Royal Proclamations, vol. I, p.161-62.

${ }^{66}$ HMC, Buccleuch, iii, p.118; Northamptonshire Record Office, Northampton (hereafter NRO), Buccleuch Letters, iv, fo.18, a, b \& c. The profile of participation suggested by the 
Boughton House pardons is discussed in both Martin, Feudalism to Capitalism, p.201; and Manning, Village Revolts, p.242.

${ }^{67}$ Martin, Feudalism to Capitalism, pp.195-96. The earl of Huntingdon subsequently sent Cecil a list of all the rebels who had submitted in Leicestershire, though it does not appear to have survived. HMC, Calendar of the Manuscripts of the Most Honourable the Marquess of Salisbury, preserved at Hatfield House, Hertfordshire. Pt.19, (A.D. 1607), London, 1965, p.347 (29 Nov. 1607).

${ }^{68}$ Clive Holmes, Seventeenth-Century Lincolnshire, Lincoln, 1980, pp.52-55, citing (p.47n.1) a concept developed by the anthropologists Redfield and Skinner.

${ }^{69}$ Peter McCullough, Sermons at Court: Politics and Religion in Elizabethan and Jacobean Preaching, Cambridge, 1998, pp.128, 189. Although Helen C. White, Social Criticism in Popular Religious Literature of the Sixteenth Century, London, 1944, pp.171-72, explicitly compares Wilkinson to Robert Crowley, the more apposite comparison is with Thomas Becon. See p.18 [text at n.82] below.

${ }^{70}$ Lori-Ann Ferrell, Government by Polemic: James I, the King's Preachers, and the Rhetorics of Conformity, 1603-1625, Stanford, 1998, pp.38-40; Ferrell, 'The Sacred, the Profane, and the Union: Politics of Sermon and Masque at the Court Wedding of Lord and Lady Hay', in Thomas Cogswell, Richard Cust and Peter Lake (eds), Politics, Religion and Popularity: Early Stuart Essays in Honour of Conrad Russell, Cambridge, 2002, pp.53-55; Ian Green, Print and Protestantism in Early Modern England, Oxford, 2002, p.670.

${ }^{71}$ Wilkinson's sermon is only briefly alluded to by Martin, Feudalism to Capitalism, pp.163, 176, 179 (where it is taken to reflect the government's thinking); and by Manning, Village Revolts, pp.233, 235 (who cites it only second-hand). It has, however, attracted rather more attention from literary critics, for reasons which will become clear (see section V, below). For the rhetoric and content of assize sermons, see Juliet Ingram, 'The Conscience of the Community: The Character and Development of Clerical 
Complaint in Early Modern England, Unpublished Ph.D. Dissertation, University of Warwick, 2004, ch.2.

${ }^{72}$ Robert Wilkinson, A Sermon Preached at North-Hampton the 21 of June Last Past Before the Lord Lieutenant of the County and the Rest of the Commissioners There Assembled Upon Occasion of the Late Rebellion and Riots in Those Parts Committed, London, 1607, sigs.C4 $4^{\mathrm{v}}, \mathrm{F} 1^{\mathrm{r}}-1^{\mathrm{v}}$.

${ }^{73}$ Wilkinson, A Sermon Preached at North-Hampton, sigs.A3-3v .

${ }^{74}$ Wilkinson, A Sermon Preached at North-Hampton, sig. $3^{v}$.

${ }^{75}$ Wilkinson, A Sermon Preached at North-Hampton, sig.B1 ${ }^{\mathrm{r}}$.

${ }^{76}$ Wilkinson, A Sermon Preached at North-Hampton, sigs.B1 ${ }^{\mathrm{v}}, \mathrm{B} 2^{\mathrm{r}}$.

${ }^{77}$ Wilkinson, A Sermon Preached at North-Hampton, sigs.E3 ${ }^{\mathrm{r}}-3^{\mathrm{v}}$.

${ }^{78}$ Wilkinson, A Sermon Preached at North-Hampton, sig.F1 ${ }^{\mathrm{r}}$.

${ }^{79}$ Wilkinson, A Sermon Preached at North-Hampton, sig.A3 ${ }^{\mathrm{v}}$.

${ }^{80}$ Wilkinson, A Sermon Preached at North-Hampton, sig. A4 ${ }^{\mathrm{r}}$.

${ }^{81}$ Wilkinson, A Sermon Preached at North-Hampton, sig.D2 ${ }^{\mathrm{r}}$.

${ }^{82}$ Wilkinson, A Sermon Preached at North-Hampton, sigs.C3 ${ }^{\mathrm{v}}-\mathrm{C} 4^{\mathrm{r}}$; Thomas More, The Yale Edition of the Complete Works of St Thomas More, volume 4: Utopia, eds. E. Surtz and J.H. Hexter, New Haven, 1965, p.65; and cf. Thomas Becon, The Jewel of Joy, London, ?1550, sigs $\mathrm{G} 8^{\mathrm{v}}-\mathrm{H} 1^{\mathrm{r}}$.

${ }^{83}$ Wilkinson, A Sermon Preached at North-Hampton, sig.C4 ${ }^{\mathrm{r}}$.

${ }^{84}$ Wilkinson, A Sermon Preached at North-Hampton, sigC4v .

${ }^{85}$ Wilkinson, A Sermon Preached at North-Hampton, sig.D3 ${ }^{\mathrm{r}}$.

${ }^{86}$ Steve Hindle, On the Parish? The Micro-Politics of Poor Relief in Rural England, c.1550-1750, Oxford, 2004, pp.81-92

${ }^{87}$ Thomas Becon, The Fortresse of the Faithful, London, 1550, sig.E4 ${ }^{\mathrm{v}}$. Becon also noted the parallel proverbs that 'honger is sharper than thorne'; that 'necessetie is an harde darte'; and that 'nede maketh the old wife trot'. Morris P. Tilley, A Dictionary of the Proverbs in England in the Sixteenth and Seventeenth Centuries, Ann Arbor, 1950, p.43 
[no.B286] traces the belly proverb back as early as 1539 when it first appeared in Richard Taverner's translation of Erasmus' Adages.

${ }^{88}$ Wilkinson, A Sermon Preached at North-Hampton, sigs.D3 ${ }^{\mathrm{r}}-\mathrm{D} 4^{\mathrm{r}}$.

${ }^{89}$ TNA: PRO, C181/2 is the chancery commission

${ }^{90}$ Wilkinson, A Sermon Preached at North-Hampton, sig.F2v.

${ }^{91}$ Wilkinson, A Sermon Preached at North-Hampton, sig.F1 ${ }^{\mathrm{v}}$.

${ }^{92}$ For the social and political significance of murmuring, see Wood, The 1549 Rebellions, pp.91-142.

${ }^{93}$ Wilkinson, A Sermon Preached at North-Hampton, sig.F2 ${ }^{\mathrm{r}}$.

${ }^{94}$ Wilkinson, A Sermon Preached at North-Hampton, sig.F2r.

${ }^{95}$ Wilkinson, A Sermon Preached at North-Hampton, sigs.F2 ${ }^{\mathrm{r}}-\mathrm{F} 2^{\mathrm{v}}$.

${ }^{96}$ Wilkinson, A Sermon Preached at North-Hampton, sig.F2v. Cf. Walter, 'A "Rising of the People"?', p.80. For the land of Cockaigne as the 'poor man's heaven', see A.L. Morton, The English Utopia, London, 1952, pp.11-34; F. Graus, 'Social Utopias in the Middle Ages', Past and Present no.38, December 1967, esp. pp.9-10; G. Beauchamp, 'The Dream of Cockaigne: Some Motives for the Utopias of Escape', The Centennial Review 25, 1981, pp.345-62; and Herman Pleij, Dreaming of Cockaigne: Medieval Fantasies of the Perfect Life, trans. D. Webb, New York, 2001. For the endurance of the image in oral culture, see Frederick B. Jonassen, 'Lucan's Saturnalia, the Land of Cockaigne, and the Mummers Plays', Folklore 101, 1990, 58-68.

${ }^{97}$ Wilkinson, A Sermon Preached at North-Hampton, sig.F3 ${ }^{\mathrm{r}}$.

${ }^{98}$ Wilkinson, A Sermon Preached at North-Hampton, sig.F3 ${ }^{\mathrm{v}}$.

${ }^{99}$ Wilkinson, A Sermon Preached at North-Hampton, sig.F4 ${ }^{\mathrm{r}}$. For penitence on the gallows, see J.A. Sharpe, "'Last Dying Speeches": Religion, Ideology and Public Execution in Seventeenth-Century England', Past and Present no.107, 1985, 144-67.

${ }^{100}$ Wilkinson, A Sermon Preached at North-Hampton, sig.D3. For an equally materalist reading, see the plea of the distressed poor of Somerset that they could not eat stones. 
Steve Hindle, 'Dearth and the English Revolution: The Harvest Crisis of 1647-50', Economic History Review (Online Early 2007), 27-28.

${ }^{101}$ Arber (ed), A Transcript of the Registers of the Company of Stationers, vol.III, p.355 (7 July 1607).

${ }^{102}$ Markku Peltonen, 'Francis Bacon, Viscount St Alban (1561-1626)', ODNB.

${ }^{103}$ Francis Bacon, 'Of Seditions and Troubles', in The Oxford Francis Bacon, volume XV: The Essayes or Counsels, Civill and Morall, ed. M. Kiernan, Oxford, 1985, pp.43-50 (all subsequent quotations are from Kiernan's edition, citing the line numbers in the text). The earliest manuscript text of the essay survives as BL, MS Harley, 5106, fos. $28^{\mathrm{r}}-29^{\mathrm{v}}$. The textual and contextual evidence for the dating of this manuscript to $c .1607-12$, together with a discussion of the relationship between the manuscript and the greatly expanded and altered version published in 1625, is provided in Kiernan, 'Textual Introduction', in The Oxford Francis Bacon, vol. $X V$, in pp.lxxi-lxxiv, lxxxvii-lxxxix. For Bacon's interest in seditious writings as early as the mid-1590s, see Kenneth Cardwell, 'Notes and Documents: An Overlooked Tract by Francis Bacon', Huntington Library Quarterly 65, 2002, 421-33. Long-standing uncertainty about its date of composition probably explains why 'Of Seditions and Troubles' has so rarely been discussed in the context of the Midland Rising (it goes unnoticed in both Martin, Feudalism to Capitalism; and Manning, Village Revolts), although Walter, "A Rising of the People"?', p.106 suggests that Bacon gained 'invaluable copy' for the essay during the interrogation of the Oxfordshire conspirators of 1596 . For the more recent view that the essay derives from Bacon's direct observation of the political techniques of the Guise faction during the French Wars of Religion, see Martin Dzelzainis, “"The Feminine Part of Every Rebellion": Francis Bacon on Sedition and Libel, and the Beginning of Ideology', Huntington Library Quarterly 69, 2006, 139-52.

${ }^{104}$ Paul Slack, From Reformation to Improvement: Public Welfare in Early Modern England, Oxford, 1998, p.59. It is nonetheless striking that Bacon scholars, even those interested in 
his social and political attitudes, have been so reluctant to discuss of 'Of Seditions and Troubles'. The essay goes virtually unmentioned in the important essays by Theodore K. Rabb, 'Francis Bacon and the Reform of Society', in Theodore K. Rabb and Jerrold E. Seigel (eds), Action and Conviction in Early Modern Europe, Princeton, 1968, pp.169-93; and Markku Peltonen, 'Bacon's Political Philosophy', in Markku Peltonen (ed.), The Cambridge Companion to Bacon, Cambridge, 1996, pp.283-310.

${ }^{105}$ Bacon had lamented that 'insteed of a whole towne full of people' there is in the English countryside 'nought but greenefieldes, a shepheard and his dogg'. Hartley (ed.), Proceedings in the Parliaments of Elizabeth I, iii, p.231 (26 Nov. 1597).

${ }^{106}$ Kiernan, 'General Introduction', in The Oxford Francis Bacon, volume XV, p.xxxiv notes that such structural clarity was relatively unusual in Bacon's earlier essays.

${ }^{107}$ Cf. Ian W. Archer, The Pursuit of Stability: Social Relations in Elizabethan London, Cambridge, 1991, p.257.

${ }^{108}$ For the historiographical resonance of this phrase, which has been taken to symbolise a misguided reading of popular protest as spasmodic and instinctive, see Edward Thompson, 'The Moral Economy of the English Crowd in the Eighteenth Century', reprinted in Thompson, Customs in Common, London, 1991, p.186.

${ }^{109}$ Fletcher and MacCulloch, Tudor Rebellions, esp. pp.123-32.

${ }^{110}$ R.W.K. Hinton, 'The Mercantile System in the Time of Thomas Mun', Economic History Review 7:3, 1955, p.280.

${ }^{111}$ N.B. Harte, 'State Control of Dress and Social Change in Pre-Industrial England', in D.C. Coleman and A.H. John (eds), Trade, Government and Economy in Pre-Industrial England, London, 1976, pp.132-65; Hindle, On the Parish?, pp.109-20. Cf. the suggestion that Bacon's catalogue of desiderata for the purpose of repressing sedition 'would not have aroused dissent from the governing class of England at any time from the fourteenth to the eighteenth centuries'. D.C. Coleman, 'Mercantilism Revisited', Historical Journal 23:1, 1980, p.78. 
${ }^{112}$ Thirsk, 'Enclosing and Engrossing', p.227; Paul Slack, Poverty and Policy in Tudor and Stuart England, London, 1988, pp.122-31; Slack, 'Dearth and Social Policy'. The themes of social welfare and market regulation are very effectively combined in Slack, 'Absolute Power', in Slack, From Reformation to Improvement, pp.53-76.

${ }^{113}$ The most useful recent discussions of the commonwealthsmen are Wood, Foundations of Political Economy, ch.8; and McRae, God Speed the Plough, ch.1. It is particularly striking that Bacon should argue in favour of 'the Regulating of Prices of things vendible', for the ambiguous power to fix prices had been a matter of great sensitivity in the policy statements associated with the 'dearth orders' through which the Elizabethan and early Stuart regimes sought to intervene in grain markets. See Hindle, 'Dearth and the English Revolution', p.12 nn.59-60. In January 1620, Bacon would propose to King James a series of 'commonwealth commissions' which in effect reads like a draft (or a revision?) of the corresponding section in 'Of Seditions and Troubles': his list of projects included 'advancing the clothing of England, as well the old drapery as the new'; 'staying treasure within the realm, and the reiglement of monies'; 'the provision of the realm with corn and grain', 'the government of the exportation and importation thereof' and 'the directing of public granaries'; 'introducing and nourishing manufactures within the realm, for the setting people a-work', the 'prevention of depopulations of towns and houses of husbandry'; the 'recovery of drowned lands'; 'the suppression of the grievances of informers'; 'the better proceedings in the plantations of Ireland'; and 'the provision of the realm with all kind of warlike defence'. The Works of Francis Bacon, eds. J. Spedding, R.L. Ellis and D.D. Heath, 14 vols, London, 1857-74, vii, 72-73.

${ }^{114}$ In addition to his speech of 1597 (see above pp.21, 57 [text at and in n.105]), Bacon had spoken in support of the continuance of the tillage law in 1601, remarking that 'it standes not with the pollecye of the State that the welth of the kingdome shoul be engrossed into a ffewe pasturers'. Hartley (ed.), Proceedings in the Parliaments of Elizabeth I, iii, 451 (9 Dec. 1601). For his subsequent praise (drafted in the early 1620s and published 
in 1622) of early Tudor policy against enclosure, see The History of the Reign of King Henry VII, in Bacon, Works, vi, pp.93-94.

${ }^{115}$ Walter, 'Crown and Crowd', p.15.

${ }^{116}$ Slack, From Reformation to Improvement, p.59.

${ }^{117}$ Bacon, Works, vii, p.116.

118 John Walter, 'Public Transcripts, Popular Agency and the Politics of Subsistence in Early Modern England', reprinted in Walter, Crowds and Popular Politics, pp.196-222.

${ }^{119}$ Hughes and Larkin (eds), Stuart Royal Proclamations, vol. I, p.154.

${ }^{120}$ All references (citing here the opening stage direction) are to the Arden Shakespeare edition, ed. Philip Brockbank, London, 1976. There is an emerging consensus, based both on probable performance history and on internal textual evidence, that the play can be dated to 1608. See, e.g., Martin Wiggins, 'The King's Men and After', in Jonathan Bate and Russell Jackson (eds), Shakespeare: An Illustrated Stage History, Oxford, 1994, p.29; and David George, 'Plutarch, Insurrection and Dearth in Coriolanus', Shakespeare Survey 53, 2000, pp.60-72. For alternative views, see W.G. Zeeveld, 'Coriolanus and Jacobean Politics', Modern Literature Review 57, 1962), p.321 (who suggests 1606); Richard Wilson 'Against the Grain: Representing the Market in Coriolanus', reprinted in Wilson, Will Power: Essays on Shakespearean Authority, Hemel Hempstead, 1993, p.117 (who suggests after 1604 but before 1607); and Annabel Patterson, Fables of Power: Aesopian Writing and Political History, Durham NC, 1991, p.121 (who suggests late 1609). There is a recent convention, endorsed in the subsequent discussion, among literary critics that the protagonist is better referred to as 'Martius' rather than by the cognomen 'Coriolanus', which is not given until very late in 1.1. Cf. Cathy Shrank, 'Civility and the City in Coriolanus', Shakespeare Quarterly 54, 2003, p.409n.13.

${ }^{121}$ For the sources, see Coriolanus, ed. Brockbank, pp.29-35.

${ }^{122}$ E.C. Pettet, 'Coriolanus and the Midlands Insurrection of 1607', Shakespeare Survey 3, 1950, pp.36-37; Andrew Gurr, 'Coriolanus and the Body Politic', Shakespeare Survey 28, 
1975, pp.66-67; James Holstun, 'Tragic Superfluity in Coriolanus', English Literary History 50, 1983, pp.486-87; George, 'Plutarch, Insurrection and Dearth', pp.60-61.

${ }^{123}$ These analogies were first noticed by Pettet, 'Coriolanus and the Midlands Insurrection', pp.37-38, 39-40.

${ }^{124}$ George, 'Plutarch, Insurrection and Dearth', pp.63, 67.

${ }^{125}$ George, 'Plutarch, Insurrection and Dearth', p.61. Cf. the view that Coriolanus speaks more to issues of metropolitan food supply in the late 1590s: Buchanan Sharp, 'Shakespeare's Coriolanus and the Crisis of the 1590s', in Buchanan Sharp and Mark Fissel (eds.), Law and Authority in Early Modern England: Essays Presented to Thomas Garden Barnes, Newark N.J, 2007, pp.27-63.

${ }^{126}$ For a similarly close contextual reading of Shakespeare's representation of early Stuart electoral politics in Coriolanus 2.2, see Mark A. Kishlansky, Parliamentary Selection: Social and Political Choice in Early Modern England, Cambridge, 1986, pp.3-9.

127 Pettet, 'Coriolanus and the Midlands Insurrection', p.39; Annabel Patterson, Shakespeare and the Popular Voice, Oxford, 1989, p.122. For an astute reading of Shakespeare's social and political attitudes in general, which curiously makes no reference at all to Coriolanus, see Blair Worden, 'Shakespeare and Politics', Shakespeare Survey 44, 1991, pp.1-15.

${ }^{128}$ Hindle, On the Parish?, pp.227-99. For developing languages of social description and dissociation, see Keith Wrightson, 'Estates, Degrees and Sorts: Changing Perceptions of Society in Tudor and Stuart England', in Penelope J. Corfield (ed.), Language, History and Class, Oxford, 1991, pp.30-52.

${ }^{129}$ Hindle, On the Parish?, pp.109-20.

${ }^{130}$ Philip Stubbes, Anatomy of Abuses, ed. F.J. Furnivall, 2 vols, London, 1877-82, i, p.105.

${ }^{131}$ Sharp, 'Shakespeare's Coriolanus', p.36.

${ }^{132}$ John Walter, 'The Social Economy of Dearth in Early Modern England', reprinted in Walter, Crowds and Popular Politics, p.151, 
${ }^{133}$ Martius' list of proverbs bears comparison with that cited in 1550 by Thomas Becon. See p.54 [text in n.87] above. For the importance of proverbs in the oral culture of the period, see David Rollison, The Local Origins of Modern Society: Gloucestershire, 1500-1800, London, 1992, pp.67-83; Fox, Oral and Literate Culture, pp.112-72; and Adam Fox and Daniel Woolf, 'Introduction', in Adam Fox and Daniel Woolf (eds), The Spoken Word: Oral Culture in Britain, 1500-1900, Manchester, 2002, pp.29-31. Of the 143 'rebels' pardoned by Montagu at Boughton House, 116 (81\%) were functionally illiterate, making only a mark rather than signing their names. NRO, Buccleuch Letters, iv, fo.18, a, b \& c. ${ }^{134}$ Brockbank (Coriolanus, p.110n) helpfully traces contemporary parallels for the first of the four proverbs. The 'emergent slogan' implied by the fourth echoes the warnings of Somerset vagrants, reported by Edward Hext to Lord Treasurer Burghley in September 1596 that 'the ritche men have gotten all into ther hands and will starve the poore'. R.H. Tawney and E. Power (eds), Tudor Economic Documents, 3 vols, London, 1924, ii, p.341. ${ }^{135}$ Thompson, 'Moral Economy of the English Crowd'. Two critics have pointed out the Thompsonian resonances of Coriolanus 1.1, though neither regards the moral economy as a feature of the Midland Rising. Patterson, Shakespeare and the Popular Voice, pp.132-34 warns against a neo-Thompsonian reading which would dismiss the Midland Rising simply as an extreme form of ritual process. Although Wilson, 'Against the Grain', p.89 dates the composition of the play before the Midland Rising, he nonetheless argues that Shakespeare's plebeians, like grain rioters, 'express themselves with confidence and discipline in the idiom of Thompson's moral economy, intended not as a simple reflex to dearth but at preventing the market imperative from draining supply'. On the manyheaded monster, see C.A. Patrides, “"The Beast With Many Heads”: Renaissance Views on the Multitude', Shakespeare Quarterly 16, 1965, pp.241-46; Christopher Hill, 'The Many-Headed Monster in Late Tudor and Early Stuart Political Thinking', reprinted in Hill, Change and Continuity in Seventeenth-Century England, rev. edn, New Haven, 1991, pp.181-204. 
${ }^{136}$ Walter, 'The Social Economy of Dearth', pp.155-57.

${ }^{137}$ Andrew Hadfield, Shakespeare and Renaissance Politics, London, 2004, p.172.

${ }^{138}$ See p.14 [text at n.56] above.

${ }^{139}$ Cf. James C. Scott, Domination and the Arts of Resistance: Hidden Transcripts, New Haven, 1990, pp.4-5, 206-12.

${ }^{140}$ Walter and Wrightson, 'Dearth and the Social Order', pp.27-29.

${ }^{141}$ TNA: PRO, SP10/5/20 ('As this scarcity comes by man, so it may be redressed by man'); S.R. Gardiner (ed.), Reports of the Cases in the Court of Srar Chamber and High Commission, Camden Soc., $2^{\text {nd }}$ ser., xxxix, 1886, p.46 ('This last yeares famin was made by man and not by God'). For popular critiques of 'dearth without scarcity' in the 1640s, see Hindle, 'Dearth and the English Revolution', pp.23-24. For the ballad literature, see p.11 [text at n.42] above.

${ }^{142}$ Shrank, 'Civility and the City', p.413 notes that all four of the sources-North's translation of Plutarch; Holland; Sidney; and Livy—simply offer authoritative thirdperson accounts of the rhetorical success of the speech, and that only North concedes that its achievement was conditional, dependent on the creation of the tribunate.

${ }^{143}$ Menenius' subsequent ironic commentary on the citizens' success (five allusions to their 'fair works' in $4.6 .96,101,118,119,148$ ) might equally be read as an oblique reference to John Reynolds avowed policy of 'making fair works' in 1607. See p.7 [text at n.33] above.

${ }^{144}$ Karen Edwards, 'Cormorant', Milton Quarterly 39, 2005, pp.258-259; Brodie Waddell, 'Economic Immorality and Social Reformation in English Popular Preaching, 15851625', Cultural and Social History 5:2, May 2008, 172.

${ }^{145}$ Thomas Elyot, The Boke Named the Governor, ed S.E. Lehmberg, London, 1962, p.216; Robert Crowley, 'The Waie to Wealth' [1550], in Cowper (ed.), Select Works, p.132; Becon, The Jewel of Joy, sig.G3v; Three Sermons, or Homelies to Move Compassion Towards the Poor 
and Needy, London, 1596, sig.G2 ${ }^{\mathrm{v}}$; J.R Dasent (ed.), Acts of the Privy Council of England, vol. XXVII, 1597, London, 1903, p.359.

${ }^{146}$ John Brinsley, The Third Part of the True-Watch, London, 1623, pp.237, 239.

${ }^{147}$ An anonymous supporter of the bills for the maintenance of tillage introduced in 1597 noted that 'there groweth cleanenes of teeth through scarcity of breade'. Hartley (ed.), Proceedings in the Parliaments of Elizabeth I, iii, p.217. For the deployment of this idiom in the polemics of the late 1640s, see Hindle, 'Dearth and the English Revolution', p.7. The allusion is to Amos iv: 6 ('And I also have given you cleanness of teeth in all your cities, and want of bread in all your places: yet have ye not returned unto me').

148 Wilkinson, A Sermon Preached at North-Hampton, sig.E1 ${ }^{\mathrm{r}}$, makes repeated use of the idiom of 'fragments' in rehearsing the parable of Christ feeding the five thousand in Mark viii: 19 and Matthew xiv: 19.

${ }^{149}$ For Leicester, see Gay, 'Midland Revolt', p.214 n.2; Martin, Feudalism to Capitalism, p.171; Manning, Village Revolts, pp.234-5. For the earl of Huntingdon's staging of mock hangings at a Leicestershire windmill, see HMC, Hastings, iv, 194 (earl of Huntingdon to the PC, 14 June 1607).

${ }^{150}$ King James himself could be similarly euphemistic in referring to the grotesque judicial penalty for treason. Hughes and Larkin (eds), Stuart Royal Proclamations, volume I, p.155.

${ }^{151} \mathrm{Cf}$. the idiom popularly used to describe the judicial carnage in the aftermath of Cade's rebellion. I.M.W. Harvey, Jack Cade's Rebellion of 1450, Oxford, 1991, p.152.

${ }^{152}$ Hughes and Larkin (eds), Stuart Royal Proclamations, volume I, p.161.

${ }^{153}$ For this last suggestion, see Patterson, Fables of Power, p.123.

${ }^{154}$ Thomas Carew, 'A Caveat for Craftsmen and Clothiers', in Carew, Certaine Godly and Necessarie Sermons, London, 1603, sig.T2 ${ }^{\mathrm{v}}$, a compressed allusion to both Psalms xvii: 14 and Luke xii: 18 (for the context, see Patrick Collinson, 'Christian Socialism in Elizabethan Suffolk: Thomas Carew and His Caveat for Clothiers', in Carol Rawcliffe, 
Roger Virgoe and Richard Wilson (eds.), Counties and Communities: Essays on East Anglian History, Norwich, 1996, pp.161-79; B.W. Quintrell (ed.), The Maynard Lieutenancy Book, 1608-1639, Chelmsford, 1993, p.259 (for the context, see John Walter, 'Grain Riots and Popular Attitudes to the Law: Maldon and the Crisis of 1629', reprinted in Walter, Crowds and Popular Politics, pp.27-66).

${ }^{155}$ See, for instance, the range of issues discussed in Lee Bliss, 'What Hath a QuarterCentury of Coriolanus Criticism Wrought?', in W.R. Elton and John M. Mucciolo (eds), The Shakespearean International Yearbook, 2: Where are We Now in Shakespearean Studies?, Aldershot, 2002, pp.63-75.

${ }^{156}$ See p.9 [text at n.36] above.

${ }^{157}$ Although Sir Edmund Tilney, master of the revels, had required the portrayal of the 'Ill May Day' insurrection in Sir Thomas More 'to be wholly omitted' in c.1592-3, his successor Sir George Buc does not seem to have been alarmed by the representation of the citizens' mutiny in Coriolanus. Janet Clare, “'Greater Themes for Insurrection's Arguing": Political Censorship of the Elizabethan and Jacobean Stage', Review of English Studies, new ser., 150, 1987, pp.169-83.

${ }^{158}$ Richard Saunders, Apollo Anglicanus: The English Apollo, London, 1698, sigs.A5 ${ }^{\mathrm{r}}-\mathrm{B} 8^{\mathrm{r}}$ contains a plagiarized version of Bacon's essay. For almanacs, see Bernard Capp, Astrology and the Popular Press: English Almanacs, 1500-1800, London, 1979.

${ }^{159}$ Walter, Crowds and Popular Politics.

${ }^{160}$ Edward Thompson, 'The Patricians and the Plebs', in Thompson, Customs in Common, pp.73-4.

${ }^{161}$ Andy Wood, "'Poor Men Woll Speke One Day”: Plebeian Languages of Deference and Defiance in England, c.1520-1640', in Tim Harris (ed.), The Politics of the Excluded, 1500-1850, Basingstoke, 2001, pp.67-98; Wood, 'Subordination'; Wood, 'Fear, Hatred and the Hidden Injuries of Class in Early Modern England', Journal of Social History 39:3, Spring 2006, 803-826. 
${ }^{162}$ BL MS Harley, 787/11; Wilkinson, A Sermon Preached at North-Hampton, sig.F1v.

${ }^{163}$ The literature is vast, but see most recently Hindle, 'Persuasion and Protest'; Hipkin, “"Sitting on his Penny Rent”'; Heather Falvey, 'Crown Policy and Local Economic Context in the Berkhamsted Common Enclosure Dispute, 1618-42', Rural History 12:2, October 2001, pp.123-58; and Wood, 'Subordination'.

${ }^{164}$ John Walter and Roger Schofield, 'Famine, Disease and Crisis Mortality in Early Modern Society', in John Walter and Roger Schofield (eds.), Famine, Disease and the Social Order in Early Modern Society, Cambridge, 1989, p.36. Cf. R.B. Outhwaite, 'Dearth and Government Intervention in English Grain Markets, 1590-1700', Economic History Review, 2nd ser., 33:4, November, 1981, pp. 389-406: and Hindle, 'Dearth and the English Revolution'.

${ }^{165}$ Skipp, Crisis and Development, p.37.

${ }^{166}$ Skipp, Crisis and Development, p.38.

${ }^{167}$ Cf. Buchanan Sharp, 'Popular Protest in Seventeenth-Century England', in Barry Reay (ed.), Popular Culture in Seventeenth-Century England, London, 1985, p.275. 